\title{
RESULTS OF SHORT-TERM CORROSION EVALUATION TESTS AT RAFT RIVER
}

R. L. MILLER

October 1977

\section{$\prod_{F E L E}$ Idaho, Inc.}

IDAHO NATIONAL ENGINEERING LABORATORY

\section{DEPARTMENT OF ENERGY}

IDAHO OPERATIONS OFFICE UNDER CONTRACT EY-76-C-07-1570 


\section{DISCLAIMER}

This report was prepared as an account of work sponsored by an agency of the United States Government. Neither the United States Government nor any agency Thereof, nor any of their employees, makes any warranty, express or implied, or assumes any legal liability or responsibility for the accuracy, completeness, or usefulness of any information, apparatus, product, or process disclosed, or represents that its use would not infringe privately owned rights. Reference herein to any specific commercial product, process, or service by trade name, trademark, manufacturer, or otherwise does not necessarily constitute or imply its endorsement, recommendation, or favoring by the United States Government or any agency thereof. The views and opinions of authors expressed herein do not necessarily state or reflect those of the United States Government or any agency thereof. 


\section{DISCLAIMER}

Portions of this document may be illegible in electronic image products. Images are produced from the best available original document. 
Printed in the United States of America Available from

National Technical Information Service

U.S. Department of Commerce 5285 Port Royal Road

Springfield, Virginia 22161

Price: Printed Copy $\$ 6.00$; Microfiche $\$ 3.00$

\section{NOTICE}

This report was prepared as an account of work sponsored by the United States Government. Neither the United States nor the Department of Energy, nor any of their employees, nor any of their contractors, subcontractors, or their employees, makes any warranty, express or implied, or assumes any legal liability or responsibility for the accuracy, completeness or usefulness of any information, apparatus, product or process disclosed, or represents that its use would not infring privately owned rights. 
TREE-1176

\section{RESULTS OF SHORT-TERM \\ CORROSION EVALUATION TESTS \\ AT RAFT RIVER}
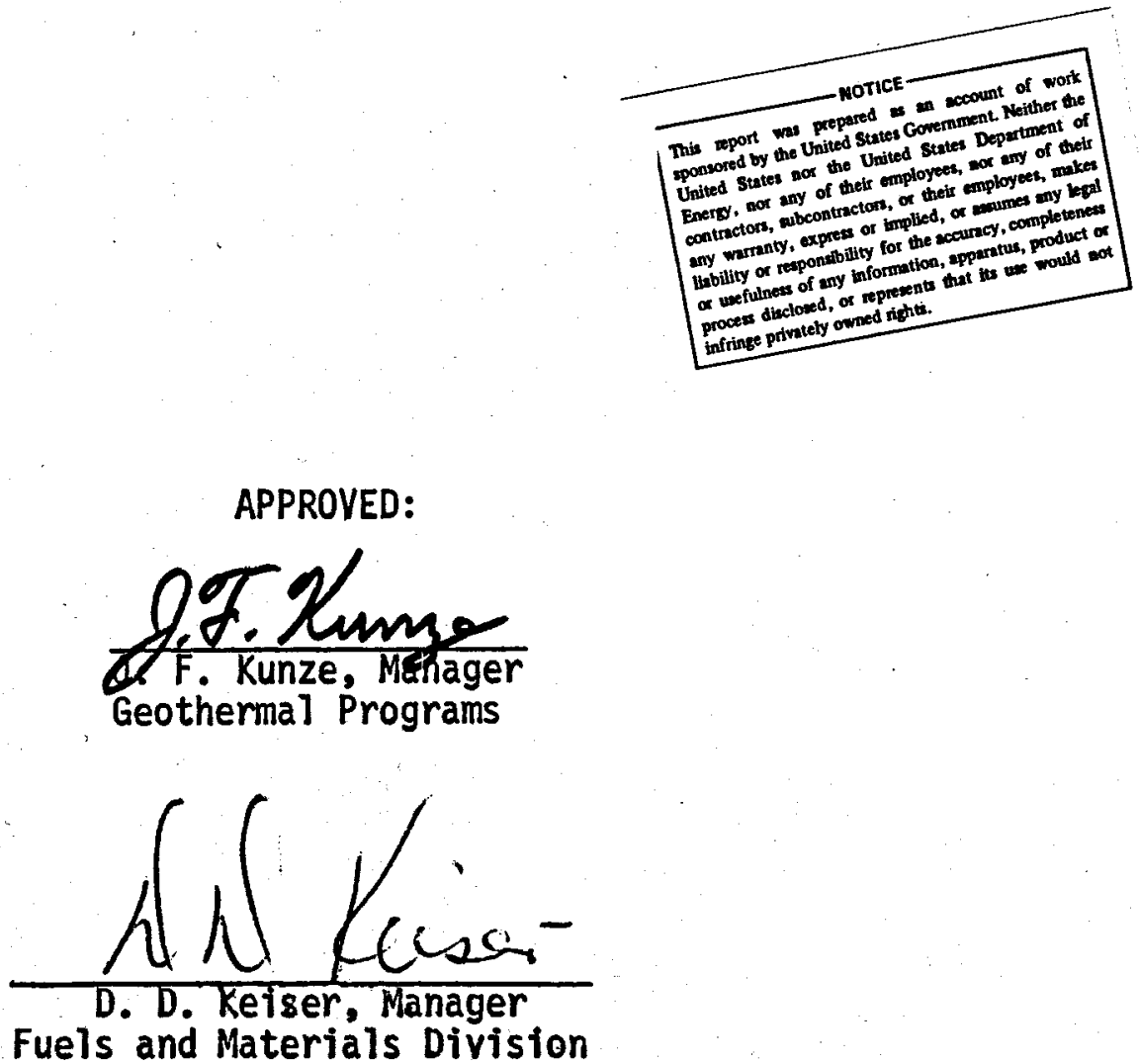


\author{
RESULTS OF SHORT-TERM \\ CORROSION EVALUATION TESTS \\ AT RAFT RIVER \\ by \\ R. L. MILLER
}

EG\&G IDAHO, INC.

October 1977

\author{
PREPARED FOR THE \\ DEPARTMENT OF ENERGY \\ DIVISION OF GEOTHERMAL ENERGY AND IDAHO OPERATIONS OFFICE \\ UNDER CONTRACT NO. EY-76-C-07-1570
}




\section{ACKNOWLEDGEMENTS}

The assistance of my colleagues in the Geothermal Project is gratefully acknowledged. Special thanks are extended to J. F. Whitbeck for his suggestions and support of this work and to G. L. Mines for his assistance in performing the tests and for the use of materials from his heat exchanger fouling test. The contributions of my colleague, H. L. Brown, in reviewing, editing and proofing this report are acknowledged with thanks. His detailed efforts have resulted in a more readable document, with a high level of accuracy in content and typography.

\section{DISCLAIMER}

Reference to a company or product by name does not imply approval or recommendation of the product by the U. S. Department of Energy or EG\&G Idaho, Inc. to the exclusion of others that may have the same properties. 


\begin{abstract}
Four categories of short-term materials evaluation tests were conducted in geothermal fluid from Raft River Geothermal Experiment, Well No. 1, to obtain corrosion data relevant to the design of the Raft River Thermal Loop Facility. Test programs are described and the testing philosophies are discussed. All materials and configurations which were tested are identified and details of posttest visual examinations are presented. The materials are then assigned to appropriate performance categories on the basis of test behavior, and the possible service limitations are appraised.
\end{abstract}


A series of short-term corrosion evaluation tests were conducted in elevated-temperature geothermal fluids from Well No. 1 of the Raft River Geothermal Experiment. These tests were designed to identify, quickly, the adverse effects of the fluids on candidate structural materials in both test sample and plant component configurations. Specific purposes of the test program include:

1. Identifying suitable materials of construction.

2. Evaluating performance of a variety of materials in Raft River geothermal fluids.

Four exploratory and short-term evaluation tests were carried out. Two were general: screening tests and subsequent short-term evaluation tests. The others were more specific and were component-oriented, making use of materials which were favorably identified in the first two tests. One test examined, quantitatively, the effects of crevice and galvanic corrosion in the joint region of a heat-exchanger tube rolled into its tubesheet and floating end. The last test evaluated probable fouling factors for selected tube materials in a shell-and-tube heat exchanger. The exposed assembly from the last test was sectioned and visually examined for corrosion and corrosion-related degradation.

A comparison of fluid compositions of the three Raft River sources, Great Salt Lake and seawater indicates appreciable differences throughout. Several constituents of Raft River geothermal fluids that are of interest in terms of potential corrosion and scaling effects on energy conversion equipment are identified and their behavior discussed. These include chloride, bicarbonate, carbonate, and sulfide anions; carbon dioxide and hydrogen sulfide gases; iron, calcium, and magnesium cations, alkali metal ions; and silica.

Briefly, the test data were definitive with respect to both suitable and unsuitable materials for Raft River geothermal fluid service: 
Aluminum alloys, most copper/nickel-bearing alloys, plain carbon steels, low alloy steels, martensitic and austenitic stainless steels (except for two special austenitic alloys) are generally unsuitable.

Brasses and bronzes (except nickel-bearing alloys), cast iron and steel in thick sections, Allegheny-Ludlum alloys $6 \mathrm{X}$ and 216, two ferritic stainless steel alloys (A-L 29-4 and 29-4-2), Hastelloy G and Inconel 625 nickel-base alloys, Haynes 6B cobalt-base alloy, and titanium are all usable with proper precautions.

Five categories of materials acceptability and the related criteria are set forth; and each material tested is assigned to an appropriate category on the basis of test behavior.

Detailed descriptions of materials appearance at intervals during the scoping and short-term tests permit effective comparisons and substantiate screening test results.

In the component-related tests, no severe galvanic or crevicecorrosion-related degradation was noted in candidate alloys for Raft River Thermal Loop Facility heat exchangers. The results of the posttest visual examination are described and discussed. Since not all of the fouling tests have been completed, posttest corrosion evaluations are reported only for titanium (no attack), AISI 304 stainless steel (no attack), and Monel 400 (little effect).

The final section of this report sets forth, and justifies, additional testing requirements for support of the proposed Thermal Loop Facility at Raft River. The high-priority portions of this work involve:

1. Galvanic couple and welded material short-term evaluation testing in fluids from other Raft River geothermal wells,

2. Cooling tower tests on materials and water treatments,

3. Materials problems induced by heat exchanger layup. 
Other, lower-priority, engineering studies which must eventually be undertaken are described in order of their priorities. 
ABSTRACT. .......................... i

SUMMARY ............................. i i

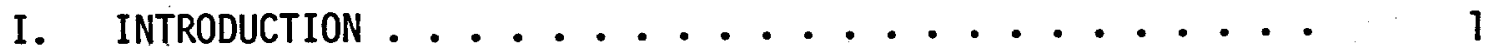

II. GEOCHEMISTRY OF THE RAFT RIVER GEOTHERMAL FLUIDS . . . . 2

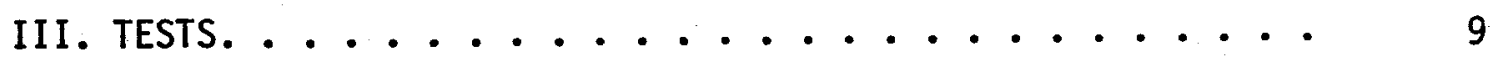



1.1 Test Location. . . . . . . . . . . . 9

1.2 Environment. ................. 10

1.3 Materials.................... 10

1.4. Test Assembly. . . . . . . . . . . 12

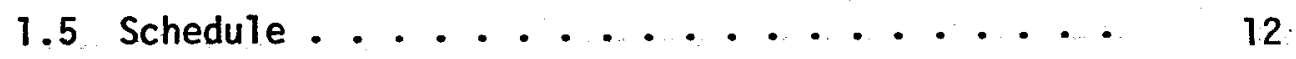

1.6 Results...................... 15

1.7 Discussion ........................... 24

2. SHORT-TERM MATERIALS EVALUATION TESTS ...... 32

2.1 Test Location. . . . . . . . . . . . 32

2.2 Environment. . . . . . . . . . 33

2.3 Materials. . . . . . . . . . 33

2.4 Test Assembly. . . . . . . . . . 36

2.5 Planned Interval Test Schedule . . . . . . 36

2.6 Results................... 38

2.7 Discussion and Conclusions. . . . . . . 44

3. TUBE-TO-TUBESHEET TEST ............. 50

3.1 Test Location. . . . . . . . . . 50

3.2 Environment. ............ 50

3.3 Materials. ................ 50

3.4 Test Assembly. . . . . . . . . . 52

3.5 schedule .............. 55 
3.6 Results. . . . . . . . . . . 55

4. SHELL-AND-TUBE HEAT EXCHANGER FOULING TESTS:

POSTTEST EXAMINATION FOR CORROSION. ....... 61

4.1 Test Location. . . . . . . . . . 61

4.2 Environment. ............... 61

4.3 Materials....................... 62

4.4 Test Assembly. ................ 62

4.5 Schedule ................ 64

4.6 Results.................. 64

4.7 Conclusion ............... . . 66

IV. OVERALL CONCLUSIONS AND RECOMMENDATIONS. ...... 67

v. REFERENCES ..........................

APPENDIX - COMPOSITION OF ALLOYS USED IN TESTS. . . . . 76 


\section{FIGURES}

\section{PAGE}

1. Comparisons of RRGE 1,2, 3 fluids with Great

Salt Lake brine and with seawater. ...........

2. Coupons, washers and insulating materials used

in test assemblies .............. 13

3. Test assembly being inserted into test section ........ 14

4. Streaks of muscovite on coupon ............. 21

5. Ball valve coated with calcite . . . . . . . . 22

6. Microtubercles .................. 23

7. Corrosion rate as a function of copper content for several copper alloys................. 29

8. Copper/zinc phase diagram. ............ 30

9. Copper/nickel phase diagram. . . . . . . . . . 30

10. Electrochemical potentials for several materials in flowing seawater. . . . . . . . . . . . . 31

11. Mobile Components-Test Trailer . . . . . . . . . . 34

12. Schedule for conducting planned interval test. . . . . . 37

13. Tube, tubesheet and TFE Holders. . . . . . . . . . 53

14. Tube-to-Tubesheet test assembly. . . . . . . . . . 54

15. Tube assembly for heat exchanger fouling tests . . . . . 63 


\section{TABLES}

Page

I. Comparison of Raft River Geothermal Fluids with

Seawater and Great Salt Lake Brine. . . . . . . .

II. Normalized Comparison of Raft River Geothermal Fluids with Seawater and Great Salt Lake Brine....... 5

III. Results of Screening Tests........... 16

IV. Corrosion Rate Data for Selected Materials from the Screening Test. ........... 25

V. Summary of Screening Test Results According to Acceptability Classes ............ 26

VI. Corrosiveness, Corrodibility, and Weight Loss Criteria........................ 39

VII. Results of Short-term Materials Evaluation Tests. ... 40

VIII. Weight Loss Data from Planned Interval Tests. . . . 45

IX. Materials for the Tube-to-Tubesheet Corrosion Test....................... 51

$X$. Exposure Schedule for Tubes in the She11-and-Tube Heat Exchanger Fouling Test .......... 64

A-I. Summary of Alloys Used in Various Materials Tests . . 77

A-II. Nominal Compositions of Aluminum Alloys Tested. . . . 78

A-III. Copper Alloys Evaluated for Geothermal Service. . . 79

A-IV. Iron-Base Alloys Evaluated for Geothermal Service . . 80

A-V. Nickel-Base Alloys Evaluated for Geothermal Service . . 81

A-VI. Nominal Compositions of Titanium and Cobalt Alloys Tested .................. 82 


\section{INTRODUCTION}

The Geothermal Project at the Idaho National Engineering Laboratory (INEL) of the Energy Research and Development Administration (ERDA) has identified materials selection as a major problem in geothermal plant design and fabrication. The tests reported here were undertaken primarily to evaluate the performance of selected candidate materials in the Raft River geothermal fluids.

This document is a report of four exploratory and short-term evaluation tests conducted at the Raft River Geothermal test facility. These tests consisted of:

1. A screening test designed to evaluate a number of alloy systems that have proven worthwhile in seawater and desalination applications.

2. A short-term evaluation test to study materials that passed the screening tests and to examine some additional materials for potential use.

3. A tube-to-tubesheet test designed to study galvanic and crevice corrosion in typical tubesheet and tube material combinations.

4. An examination of tubes, tubesheets and floating ends from a heat exchanger after a fouling test, for possible corrosion attack.

Details of these tests are contained in the sections of this report devoted to the individual tests. 
The three environmental conditions that contribute most to corrosion are: temperature, fluid composition, and fluid velocity. The rate of corrosion increases with temperature, as defined by the Arrhenius equation $[1]$, if other factors are constant. In systems open to the atmosphere there is a reduction in corrosion rate near the boiling point due to the removal of dissolved oxygen from solution [2]. The effect of temperature on corrosion of materials exposed to Raft River geothermal fluids has not been critically examined.

The effects of velocity on corrosion have been studied by a number of investigators [3-7]. Two velocities appear to be critical in corrosion performance. A lower velocity must be exceeded to decrease the chances for crevice corrosion, by preventing settling of particulate matter from the fluid stream on the bottom of the system. For example the lower critical velocity in seawater for Monel 400 and AISI Types 304 and 316 stainless steels is about $0.9 \mathrm{~m} / \mathrm{s}(3 \mathrm{ft} / \mathrm{s})^{[4]}$. If the upper critical velocity is exceeded, corrosion is accelerated due to contributions from erosion. For example the upper critical velocity in seawater for copper (CA 122) is $1.3 \mathrm{~m} / \mathrm{s}(4.4 \mathrm{ft} / \mathrm{s})$ while the upper critical velocity for $90 \mathrm{Cu} / 10 \mathrm{Ni}(\mathrm{CA} 706)$ is $4.5 \mathrm{~m} / \mathrm{s}(14.7 \mathrm{ft} / \mathrm{s})^{[7]}$. In the present tests the velocity was maintained at a nominal $1.4 \mathrm{~m} / \mathrm{s}(4.6$ $\mathrm{ft} / \mathrm{s})$.

The three production wells that have been drilled to date in the Raft River area vary in water chemistry. These three wells, in the order drilled, are referred to as RRGE 1, RRGE 2 and RRGE 3. Table I presents the identity and content of the major dissolved solids in these fluids. The high salinity of these geothermal fluids suggests a common origin with other large saline water bodies, for example, the Great Salt Lake, which is located about $160 \mathrm{~km}$ (100 mi) southeast of the Raft River Valley. The Great Salt Lake was formed when the ancient Lake Bonneville was partially drained, a relatively recent geological event ${ }^{[8]}$. Before Lake Bonneville was drained it was very close to the Raft River Valley, probably within $80 \mathrm{~km}(50 \mathrm{mi})$. After drainage of Lake Bonneville the 
salts in the undrained water concentrated due to evaporation; the Great Salt Lake and the evaporites of the salt flats are the remnants of the dissolved solids. The composition of the dissolved solids in the portion of the Great Salt Lake closest to the Raft River Valley is given in Table ${ }^{[9]}$. There is some speculation ${ }^{[10]}$ that the solids in the Great Salt Lake and its precursor, Lake Bonneville, originated as wind-carried solids from the Pacific Ocean, but other, differing theories have also been proposed ${ }^{[9]}$. The nominal composition of the dissolved solids in the oceans is given in Table $I^{[11]}$.

The concentration data in Table I were normalized by dividing by the chloride concentrations; the normalized data are collected in Table II. The purpose of normalizing the concentration data is to demonstrate similarities and differences among these sources of water. Only the major constituents are included, those contributing 0.1 weight percent or more. Other techniques for normalizing concentration data are available ${ }^{[12]}$; however, when the completeness of the analys is is considered, the present method appears to be adequate. The data are plotted in Figure 1 as the logarithm of the ion $/ \mathrm{Cl}^{-}$ratio. This treatment permits a quick visual indication of relationships but tends to accentuate differences among the small ratios.

While there are both similarities and differences among the ion $/ \mathrm{Cl}^{-}$ data for the five waters, there is little, other than the chloride contents, to suggest strikingly different corrosion properties. One constituent, dissolved oxygen, is not given in Tables I and II. Due to wind action, at least the upper strata of the ocean and the Great Salt Lake are nearly saturated with air. The oxygen content of the Raft River geothermal fluids is of the order of $0.02 \mathrm{mg} \mathrm{O}_{2} / \mathrm{kg}$ fluid. The hydrogen sulfide content of the Raft River geothermal fluids, $0.1 \mathrm{mg}$ $\mathrm{H}_{2} \mathrm{~S} / \mathrm{kg}$ fluid, and the electrochemical potential, Eh $=+105 \mathrm{mv}$ vs. SHE, would suggest the absence of even small amounts of oxygen.

Most of the corrosion data for saline waters are for service in seawater and for desalination, hence the concern here for the comparison of Raft River geothermal fluids with seawater and with Great Salt Lake brines. 
TABLE I

COMPARISON OF RAFT RIVER GEOTHERMAL FLUIDS

WITH SEAWATER AND GREAT SALT LAKE BRINE

Species

Concentration

\begin{tabular}{lcccccc} 
& Seawater & Great Salt Lake & RRGE 1 & RRGE 2 & RRGE 3 \\
\cline { 1 - 3 } $\mathrm{Na}^{+}$ & 10,561 & 77,608 & 445 & 416 & 1185 \\
$\mathrm{~K}^{+}$ & 400 & 7,840 & 31.3 & 33.4 & 97.2 \\
$\mathrm{Li}^{+}$ & 0.1 & 532 & 1.48 & 1.21 & 3.1 \\
$\mathrm{Mg}^{+2}$ & 1,272 & 9,887 & 2.35 & 0.58 & 0.60 \\
$\mathrm{Ca}^{+2}$ & 884 & 1,329 & 53.5 & 35.3 & 193 \\
$\mathrm{Sr}^{+2}$ & 13 & - & 1.56 & 1.03 & 6.7 \\
$\mathrm{~F}^{-}$ & 1.4 & - & 6.32 & 8.25 & 4.55 \\
$\mathrm{Cl}^{-}$ & 18,900 & 149,369 & 776 & 708 & 2170 \\
$\mathrm{Br}^{-}$ & 65 & 1,329 & $<1.5$ & $<1.5$ & $<1.5$ \\
$\mathrm{I}^{-}$ & 0.05 & - & 0.036 & 0.028 & - \\
$\mathrm{HCO}_{3}^{-}$ & - & - & 63.9 & 41.3 & 44.4 \\
$\mathrm{SO}_{4}^{-}$ & - & 20,811 & 60.2 & 54.1 & 53.3 \\
$\mathrm{~S}^{-}$ & - & - & 0.1 & 0.256 & - \\
$\mathrm{Note}^{-}$ & Concentrations are given in mg of dissolved species/kg of f7uid. \\
\hline
\end{tabular}


TABLE II

NORMALIZED COMPARISON OF RAFT RIVER GEOTHERMAL FLUIDS

WITH SEAWATER AND GREAT SALT LAKE 'BRINE

Species

Concentration

Seawater Great Salt Lake RRGE I

\begin{tabular}{|c|c|c|c|c|c|}
\hline & Seawater & Great Salt Lake & RRGE 1 & RRGE 2 & RRGE 3 \\
\hline $\mathrm{Na}^{+}$ & 0.559 & 0.520 & 0.573 & 0.578 & 0.546 \\
\hline$K^{+}$ & 0.0212 & 0.0525 & 0.0403 & 0.0472 & 0.0448 \\
\hline $\mathrm{Li}^{+}$ & $5.3 \times 10^{-6}$ & $3.6 \times 10^{-3}$ & $1.9 \times 10^{-3}$ & $1.7 \times 10^{-3}$ & $1.4 \times 10^{-3}$ \\
\hline $\mathrm{Mg}^{+2}$ & 0.0673 & 0.0662 & $3.0 \times 10^{3}$ & $8.2 \times 10^{-4}$ & $2.8 \times 10^{-4}$ \\
\hline $\mathrm{Ca}^{+2}$ & 0.0468 & $8.9 \times 10^{-3}$ & 0.0689 & 0.0499 & 0.0889 \\
\hline $\mathrm{Sr}^{+2}$ & $6.9 \times 10^{-4}$ & - & $2.0 \times 10^{-3}$ & $1.5 \times 10^{-3}$ & $3.1 \times 10^{-3}$ \\
\hline $\mathrm{F}^{-}$ & $7.4 \times 10^{-5}$ & - & $8.1 \times 10^{-3}$ & 0.0117 & $2.1 \times 10^{-3}$ \\
\hline $\mathrm{Cl}^{-}$ & 1.0 & 1.0 & 1.0 & 1.0 & 1.0 \\
\hline $\mathrm{Br}^{-}$ & $3.4 \times 10^{-3}$ & $8.9 \times 10^{-3}$ & $<2 \times 10^{-3}$ & $<2 \times 10^{-3}$ & $<2 \times 10^{-3}$ \\
\hline$I^{-}$ & $2.6 \times 10^{-6}$ & - & $4.6 \times 10^{-5}$ & $4.0 \times 10^{-5}$ & - \\
\hline $\mathrm{HCO}_{3}-$ & - & - & 0.0823 & 0.0583 & 0.0205 \\
\hline $\mathrm{SO}_{4}=$ & - & 0.139 & 0.0776 & 0.0764 & 0.0246 \\
\hline$S=$ & - & - & $1.3 \times 10^{-4}$ & $3.6 \times 10^{-4}$ & - \\
\hline
\end{tabular}




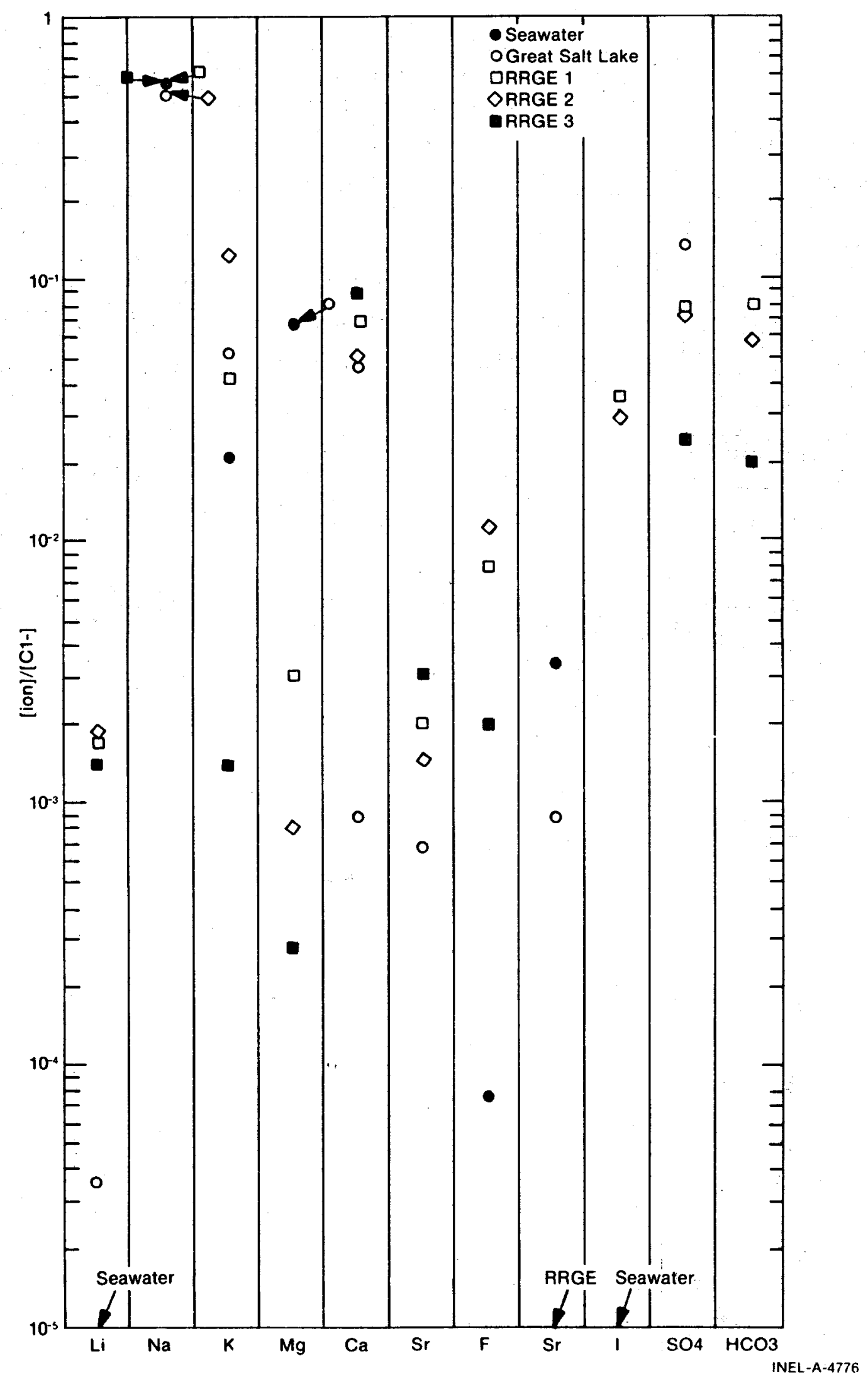

Fig. 1. Comparisons of $\operatorname{RRGE} 1,2,3$ fluids with Great Salt Lake brine and with seawater. 
Examination of Table II and Figure 1 would not encourage one to postulate that the origin of the salinity in the Raft River geothermal fluids is the Pacific Ocean or the Great Salt Lake. The origin, flow direction, age, and other geological parameters for the Raft River geothermal fluids are still unknown. However, this aspect of the geochemistry is under investigation and will be reported by others at a later date.

The geothermal fluid constituents which are of interest here are those that contribute to corrosion and/or scaling problems. These constituents, and others, are given below with a note regarding their potential impact on materials performance.

Chloride. The corrosivity of water generally increases with increasing chloride content, probably due to the formation of complex ions ${ }^{[13]}$. Relatively high concentrations of chlorides are frequently found in corrosion pits ${ }^{[14-17]}$, usually accompanied by a relatively low $\mathrm{pH}$. This combination of high chloride and acidity tends to increase corrosion within pits.

Carbon Dioxide, Bicarbonate, Carbonate. Certain temperature equilibrium relationships exist among carbon dioxide, bicarbonate ion and carbonate ion [18]. Carbon dioxide tends to increase corrosion of most structural metals, though not to the same extent as oxygen [19]. Of greater importance is the strong influence that carbon dioxide has on the solubility of calcium carbonate; calcium carbonate solubility increases with the concentration of carbon dioxide. This has two effects. The absence of a protective calcium carbonate scale may result in increased corrosion. However, the absence of this scale improves heat transfer and pumping efficiencies. Where possible, calcium carbonate scales should be avoided.

Sulfide Ion, Hydrogen Sulfide. Iron, copper and nickel tend to react with dissolved sulfides in geothermal fluids to form sulfide scales, though iron is less reactive than copper or nickel. Alloys containing both copper and nickel, for example Monel 400,70Cu/30Ni, and 
aluminum-nickel bronze, are particularly susceptible to attack by dissolved sulfides $[20,21]$.

Iron. When present as ferrous ion, iron has little effect except to form precipitates that may require removal. When present as ferric ion, iron is a strong oxidizing agent and aggressively attacks many metals. The hydrous oxides of ferrous iron are generally more soluble than those of the ferric iron. There are potential-pH relationships between these forms of iron ${ }^{[22]}$ that may be significant in the Raft River Geothermal System.

Calcium. Corrosion of most structural materials is little influenced by the presence of dissolved calcium. Calcium carbonate scales, on the other hand, tend to reduce corrosion rates by forming a barrier between the substrate metal and the geothermal fluid ${ }^{[23]}$.

Magnesium. The formation of magnesium silicates tends to protect the metal from corrosion by forming a barrier between the metal and the geothermal fluid. The magnesium silicates are relatively difficult to remove from heat exchangers, etc., by chemical cleaning procedures and are to be avoided where possible.

Silica. Silica in solution tends to retard corrosion ${ }^{[24]}$; silica scales will also act as barriers to corrosion by geothermal fluids. Unfortunately, these same scales also exacerbate heat transfer and decrease pumping efficiencies, and should be avoided where possible.

Fluoride. Fluorides are expected to have little effect on either corrosion or scaling. The major problem with fluoride is the impact of this substance on the environment.

Sodium, Potassium, Lithium. Except for their effects on the electrical conductivity of the geothermal fluid, these alkali metal ions contribute little, if anything, to either corrosion or scaling. They may properly be called "spectator ions". 


\section{TESTS}

The tests noted in the introduction are reported here in terms of a short description of the purpose, the location of the test in the Raft River test facility, the environment used in the test, the materials tested, the configuration of the test assembly, the testing schedules, the test results, and finally, the conclusions reached from the tests.

There are no established procedures for conducting corrosion tests in geothermal fluids. The procedures developed for the chemical process industries are generally applicable to the work we are doing. The American Society for Testing and Materials (ASTM), The National Association of Corrosion Engineers (NACE), and others have outlined methods for conducting corrosion tests ${ }^{[25-29]}$. In our work we have consulted these references and followed their general outline and intent.

\section{SCREENING TEST}

This exploratory test was run in two $76-\mathrm{mm}$ (3-inch Sch. 40 pipe) flow lines from valves on the wellhead control system at RRGE 1 . The primary purpose of this test was to explore, in a relatively short time, a wide variety of alloys. The results of these tests provided corrosion information on several generic classes of materials and suggested materials that should be studied more intensively. The results of these tests also suggested materials that could be eliminated from further consideration.

\subsection{Test Location}

Since this test was conducted before the Mobile Components-Test Trailer was installed at Raft River site 1, only a limited number of coupons could be installed in the flow line. Further limitations were imposed by the use of the well for reservoir studies. These limitations are discussed in more detail in the section dealing with schedules. 


\subsection{Environment}

The geothermal fluid used in this test was from RRGE 1 , and is described in Table I. The nominal temperature of the fluid was $132-135^{\circ} \mathrm{C}$ $\left(270-275^{\circ} \mathrm{F}\right)$.

The two 76-mm (3-inch Sch. 40 pipe) flow lines in the wellhead valve system were modified to permit the insertion of spools holding corrosion coupons. In one line the flow velocity was about 1.5 to $1.8 \mathrm{~m} / \mathrm{sec}(5-6 \mathrm{ft} / \mathrm{sec})$ while in the other loop, it was about 0.7 to $0.9 \mathrm{~m} / \mathrm{sec}(2.5$ to $3 \mathrm{ft} / \mathrm{sec})$.

\subsection{Materials}

A summary of the candidate materials for testing is given in Table A-I. In the following paragraphs the materials are discussed under generic classes, i.e., aluminum alloys, copper-base alloys, ironbase alloys, nickel-base alloys, and other alloys.

Aluminum Alloys. Aluminum and its alloys are known to form a refractory oxide layer over the substrate metal. This layer provides substantial corrosion resistance. These alloys have given excellent service in desalination of seawater, and several advantages from the use of aluminum alloys in this service were noted ${ }^{[30]}$.

(a) Excellent corrosion resistance when subjected to a wide variety of operating conditions.

(b) Cost reductions of up to $50 \%$ as compared with $90 \mathrm{Cu} / 10 \mathrm{Ni}$ alloys.

(c) Excellent heat transfer characteristics which allow heat exchanger sizes as much as $20 \%$ smaller than for other materials.

(d) Nontoxic corrosion products.

(e) $99 \%$ duty cycle over a 38-month period.

In this program the 1100,5052 , and 6061 alloys were selected for testing. Their nominal compositions are shown in Table A-II. 
Copper-Base Alloys. Copper-base alloys have enjoyed a history of long and useful service in seawater and desalination applications $[31,32]$. The admiralty, aluminum brass, aluminum bronze and copper-nickel alloys are particularly noteworthy in this respect ${ }^{[33]}$. Based on present trends in power plant design one would expect to see increased usage of these materials in new power plants ${ }^{[34]}$. In this test program the materials were selected from those indicated in Table A-III.

Iron-Base Alloys. In terms of cost per pound the plain carbon steels are the least expensive materials available for heat exchanger design and for piping runs. The testing of low-carbon steel and other iron-base alloys was imperative; other materials may be rated relative to the low-carbon steels. Iron-base alloys may be separated into several categories such as the plain carbon steel, low alloy steel, cast irons, and stainless steels. The materials studied in the tests reported here were selected from those listed with their nominal compositions in Table A-IV.

The most important materials in marine service are the plain carbon steels, although the low alloy steels are being used with increased frequency. The principal factors which lead to the selection of steels are ready availability, low initial cost, ease of fabrication, availability of design data, and favorable physical and mechanical properties ${ }^{[35]}$.

Nickel-Base Alloys. The nickel-base superalloys are among the most corrosion-resistant materials available for testing. Monel 400 was included with the copper-base alloys because of its relationship to the $90 \mathrm{Cu} / 10 \mathrm{Ni}$ and $70 \mathrm{Cu} / 30 \mathrm{Ni}$ alloys. The materials used in the short-term evaluation tests were Hastelloy $G$ and Inconel 625 . The compositions of these alloys are shown in Table A-V.

Other Alloys. Haynes Alloy 6B has special applications where wear resistance is required. This cobalt-base alloy was tested to ascertain its chemical stability in the geothermal fluid. The composition of Alloy $6 B$ is given in Table A-VI. 


\subsection{Test Assembly}

Corrosion coupons for the screening test were cut from sheets of 1.6 or $3.2 \mathrm{~mm}(0.062$ or $0.125 \mathrm{in}$.) thickness. The coupons were typically either $56.6 \mathrm{~mm}$ (2.33 in.) diameter or $51 \mathrm{~mm}$ (2 in.) square with an 8.3 to $9.5 \mathrm{~mm}(21 / 64$ to $3 / 8 \mathrm{in}$.) diameter mounting hole in the center of the coupon.

The corrosion coupons were electrically insulated from each other and from the mounting fixture by polytetrafluoroethylene (TFE) tubes and washers. The TFE washers were about $25.4 \mathrm{~mm}$ (1.0 in.) OD by $9.8 \mathrm{~mm}$ (0.39 in.) ID and about $5.6 \mathrm{~mm}$ ( $0.22 \mathrm{in.)}$ thick. One side of the washer was beveled about $10^{\circ}$ to provide a variable-thickness crevice. The crevice was used to accelerate or encourage crevice corrosion. Coupons and mounting materials are shown in Figure 2.

The mounting fixture was fabricated from $25.4 \times 6.3 \times 1200 \mathrm{~mm}$ (1.0 $00.25 \times 47$ in.) stainless steel bars. The bars were fitted with a cruciform of $6.3 \mathrm{~mm}(0.25 \mathrm{in}$.) rods at each end and in the middle to center the bar in the flow chamber. The fixture, shown in Figure 3 , was fabricated from AISI 304 stainless stee1. The coupons were so mounted that fluid flow was parallel to the face of the coupons.

\subsection{Schedule}

The most desirable schedule for materials testing is one that exactly simulates the operation schedules of the unit which is being simulated. This condition is seldom achieved in field testing and the test reported here does not simulate exactly the operation schedule of the $5 \mathrm{MW}(\mathrm{e})$ Thermal Loop Facility. The criteria used in establishing schedules were primarily availability of the well and the need for explicit data to meet deadlines on release of specifications for acquisition of plant equipment.

The duration of the test was based on the need for a 20-year life for the boilers and preheaters. This in turn leads to a maximum allow- 


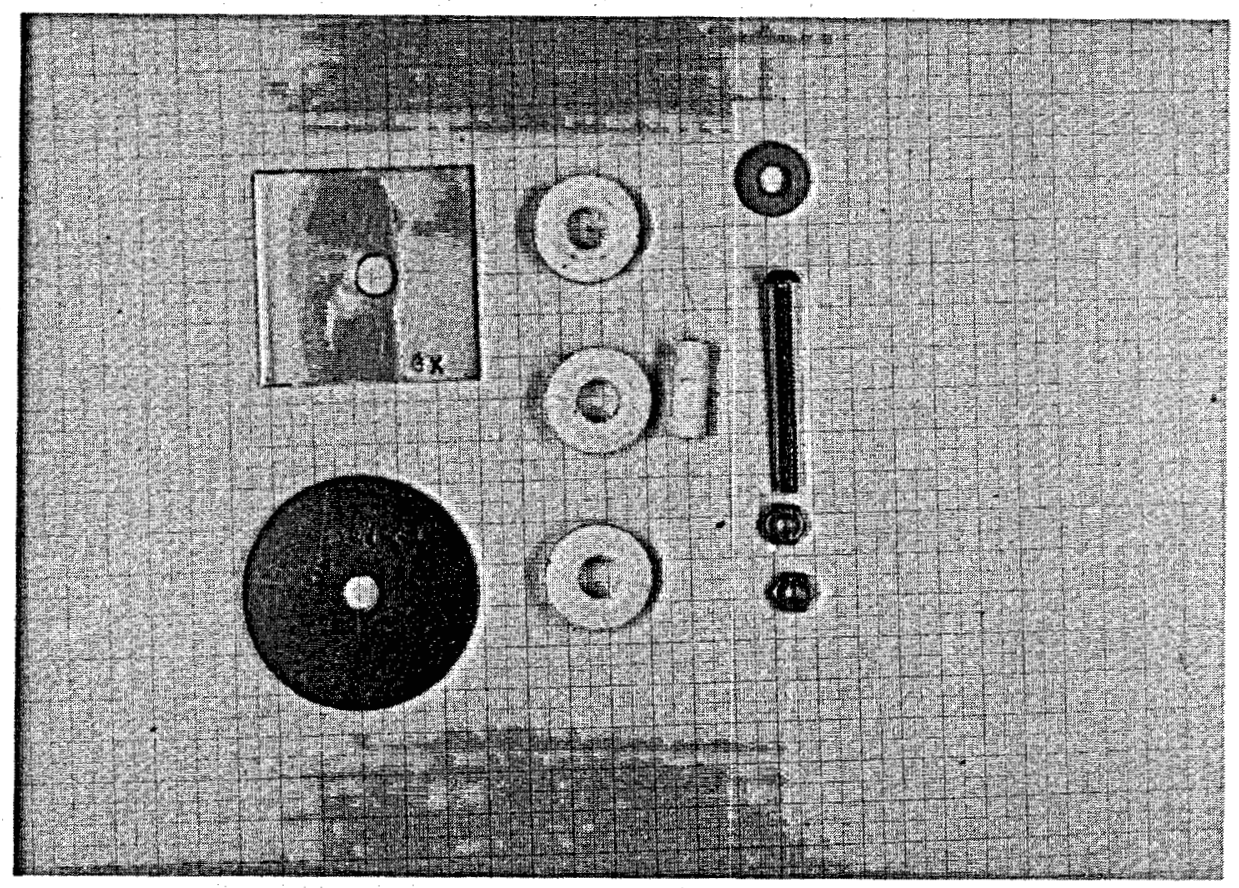

Fig. 2. Coupons, washers, and insulating materials used in test assemblies. Grid size is $1 \mathrm{~cm}$. 


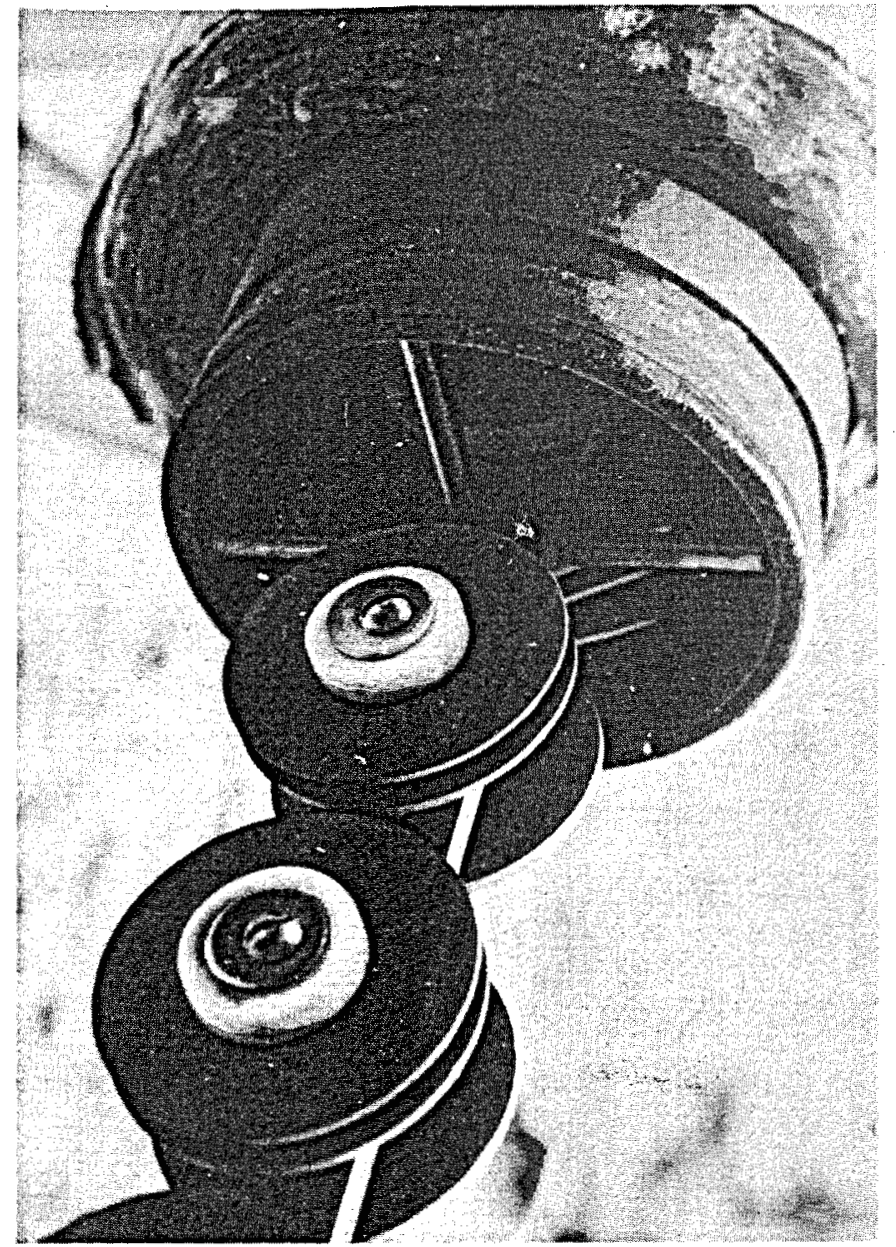

Fig. 3. Test assembly being inserted into test section.

Pipe ID is $102 \mathrm{~mm}$ (4 in. Sch. 40 Pipe). 
able corrosion rate of about $0.025 \mathrm{~mm} /$ annum $(0.001 \mathrm{in.} / \mathrm{yr}$ or $1 \mathrm{mpy})$. This criterion was used in the approximation [28]:

$$
\text { Duration of test }(\mathrm{hr})=2000 / \text { corrosion rate (mpy) }
$$

The test was terminated before the above equation was satisfied, to allow installation of the Mobile Components-Test Trailer in which subsequent tests reported herein were conducted.

The screening test was started February 27, 1976. Samples were removed after 2, 6, and 11 weeks of testing. Requirements for other testing programs, e.g., reservoir testing, precluded maintenance of a continuous flow through the test sections. About six months were required to complete the test. The sample spools remained in the system until the test was completed.

\subsection{Results}

As noted in Section III, 1 the primary purpose of the screening test was to identify materials for further testing and to eliminate some materials from further consideration as boiler and preheater materials. Because of interruptions in the test, noted in Section III, 1.5, the results are not as reliable as the first short-term evaluation test, and weight loss data were not obtained for most of the coupons. However, the coupons were examined visually, and the findings are noted in

Table III. In this table the criteria for acceptability are:

Class 1. Those materials having the best corrosion resistance to the Raft River geothermal fluid.

Class 2. Materials showing acceptable corrosion resistance to the Raft River geothermal fluid.

Class 3. Those materials which will undergo moderate corrosion attack in the Raft River geothermal fluid.

Class 4. Materials having high corrosion rates in the Raft River geothermal fluid.

Class 5. Materials having little corrosion resistance to the Raft River geothermal fluid. 
TABLE III

RESULTS OF SCREENING TESTS

Material Acceptability observations ${ }^{[a]}$

Mild Steel

ASTM A515

Gray cast iron

$9 \%-C r$ steel
4

4

2

4
Thin black scale at two weeks, black scale over yellowish scale at longer times. Numerous small pits filled with corrosion product. Corrosion increases with time, accompanied by the formation of rust-red tubercles and broad, shallow pits. Crevice corrosion developed at edge of TFE washer, no evidence of crevice corrosion under washer.

Thin black scale at two weeks. At longer times the scale thickens with the black scale overlying a yellowish deposit. Numerous small greenish dots at two weeks; the dots may be pit nuclei. At longer times there are small rust-red tubercles overlying pits and surrounded by a halo of relatively unattacked metal. The halo is probably a cathodic region with the pit being the attendant anodic zone. Scanning electron microscopy and non-dispersive $X$-ray analys is showed a relatively large amount of chloride accumulated in the pits.

Gray-black scale at two weeks, thickens with time to become a black scale overlying a yellowish deposit. Corrosion is significantly less than in low-carbon steels. No pitting noted at two weeks; at six and eleven weeks pitting was observed with very small rust-red tubercles overlying shallow, broad, localized corrosion.

Purple-brown discoloration at two weeks, color deepens with time but does not become thick as in low-carbon steels. No pitting at two weeks; however, there is some evidence of crevice corrosion at this time. At six and eleven weeks numerous pits and some greenish scale were observed.

[a] Observation intervals: 2 weeks, 6 weeks, 11 weeks. 
TABLE III (Contd)

Material Acceptability Observations ${ }^{[a]}$

Cor-Ten
(high strength
low alloy steel)

AISI 4140
(1ow alloy steel)

4

4

Haynes $6 \mathrm{~B}$

Hastelloy $G$

Inconel 625

Monel 400

.

scro

Thin black scale, yellowish when scraped, at two weeks. Scale thickens with time to yield blackgreen deposit with areas of yellowgreen scale. Numerous small, shallow, broad pits. Some halo-like areas around some pits, absent in others. Some crevice corrosion under and around TFE washer.

General black discoloration at two weeks, yellowish when scraped. Scale thickens with time. Numerous very small pit nuclei at two weeks. Pitting increased with time, with rust-red tubercles overlying pits. Pits generally surrounded by halo-like areas of immunity. Some crevice corrosion under beveled area of TFE washer and under washer.

Thin deposit of yellow-gray material, may not be corrosion product from base material. Corrosion, if any, is of the same magnitude as the surface roughness.

Deposit of water-borne mica, no other scale or discoloration noted. No evidence of corrosion.

Dense black scale overlying brittle gray scale. No evidence of pitting or crevice corrosion.

Thin, tightly adherent scale at two weeks. Scale thickens with time and becomes purple-black in color, with patches of yellow-green scale. Corrosion is not extensive; however, machining or rolling marks are deepened and broadened at six and eleven weeks. Some deposition of small calcite crystals in the occluded region between the TFE washer and insulating tube. 


\begin{tabular}{|c|c|c|}
\hline Material & Acceptability & Observations $[\mathrm{a}]$ \\
\hline $70 \mathrm{Cu} / 30 \mathrm{Ni}$ & 4 & $\begin{array}{l}\text { Gray to purple or black film at two } \\
\text { weeks. At longer times the scale } \\
\text { becomes massive and purple to black in } \\
\text { color. Machining or rolling marks } \\
\text { widened and deepened, especially under } \\
\text { beveled edge of TFE washer. Some } \\
\text { slight grooving around washer. }\end{array}$ \\
\hline $90 \mathrm{Cu} / 10 \mathrm{Ni}$ & 4 & $\begin{array}{l}\text { Gray to purple scale formed at two } \\
\text { weeks. Scale is formed from well- } \\
\text { faceted, hexagonal, tabular crystals. } \\
\text { Scale thickens with time. Corrosion } \\
\text { along machining or rolling marks is } \\
\text { more pronounced than for } 70 \mathrm{Cu} / 30 \mathrm{Ni} \\
\text { alloy. Grooving around beveled edge } \\
\text { of TFE washer is evidence of crevice } \\
\text { corrosion. }\end{array}$ \\
\hline $\begin{array}{l}\text { AMPCO } 8 \\
\text { (aluminum } \\
\text { bronze) }\end{array}$ & 2 & $\begin{array}{l}\text { Thin blue-purple film at two weeks. } \\
\text { Thickens with time to form dense } \\
\text { black scale overlying a thin yellow } \\
\text { deposit. No evidence of pitting or } \\
\text { crevice corrosion at two weeks. At } \\
\text { longer times the machining or rolling } \\
\text { marks are deepened and broadened. } \\
\text { Some minor dealloying under TFE washer. }\end{array}$ \\
\hline $\begin{array}{l}\text { AMPCO } 12 \\
\text { (aluminum } \\
\text { bronze) }\end{array}$ & 2 & $\begin{array}{l}\text { Thin blue-purple scale at two to six } \\
\text { weeks, becomes black and tightly } \\
\text { adherent at eleven weeks. Some } \\
\text { indication of nucleation of localized } \\
\text { corrosion but no good evidence of } \\
\text { corrosion at eleven weeks. }\end{array}$ \\
\hline Muntz metal & 2 & $\begin{array}{l}\text { Discolored to brown at two weeks, some } \\
\text { areas of black and green scale at } \\
\text { eleven weeks. Some dealloying under } \\
\text { TFE washer at all test intervals. } \\
\text { Machining or rolling marks deepened } \\
\text { and widened with time. Some small } \\
\text { whitish tubercles overlying small pits } \\
\text { along machining or rolling marks; } \\
\text { dealloying in pits. }\end{array}$ \\
\hline
\end{tabular}


TABLE III (Contd)

Material Acceptability Observations ${ }^{[a]}$

1700 Aluminum $\quad 5$

Light yellow to brown scale more-or-

less uniformly distributed over

surface of coupons at two weeks. Scale becomes thicker and friable with time. Areas of light brown and areas of dark gray-brown scale. Evidence of erosion at two weeks, increases at six and eleven weeks. At eleven weeks one coupon had lost more than $25 \%$ of the metal. In another coupon an impingement pit had left only $0.15 \mathrm{~mm}$ ( 0.005 in.) of the original metal thickness of $1.6 \mathrm{~mm}(0.062$ in.). This represents a loss of about $90 \%$ of its original cross section.

5052 Aluminum

6061 aluminum
Thin, friable scale, yellow to brown and gray with small areas of black deposit in more corroded areas, at two weeks. At longer times a black scale overlies yellow-gray scale. Deposition of calcite in corroded areas which are protected by overlying corrosion product, may have siliceous deposit also. Erosion significantly less than in 1100 alloy. Corrosion more general than for 1100 alloy, with small pedestals of relatively unattacked material. 01der scales extend from these pedestals to form occluded areas for calcite deposition.

Thin gray scále at two weeks. At six weeks the gray scale overlies a light green-gray deposit. Gray scale becomes black at eleven weeks. Deposition of calcite in occluded region under scale, may also have some siliceous materials associated with calcite. Little evidence of erosion; however, corrosion was extensive. Some pitting at two weeks, at longer times pitting is worse and large areas of general corrosion were seen. Some pedestals of relatively unattacked material with scale from earlier corrosion and deposition extending from these pedestals to form occluded areas for calcite deposition. There was no evidence of crevice corrosion. 
In some instances $X$-ray diffraction measurements were made to determine the specific compounds present as deposits. Generaliy, however, classification of the scales was based on color, magnetic susceptibility, or reaction with dilute hydrochloric acid.

Scaling Behavior. Between the second and sixth weeks of testing, muscovite deposited on a large number of coupons. The presence of this mineral was previously detected by $X$-ray diffraction measurements, on corrosion coupons in a fluidized-bed heat transfer experiment. The amount of muscovite found in that experiment, however, was very small compared to the amount found in the present test. Figure 4 shows streaks of muscovite on a Muntz metal corrosion coupon. In most cases the material deposits appear to follow hydrodynamic stream lines. The leading edges of several coupons also showed muscovite deposits. These observations suggest that masses of the mineral impinged on the coupons. The conditions for formation of muscovite from components in the geothermal fluid are very close to those reported elsewhere ${ }^{[36]}$, and scale formation by this mechanism must be considered. Some silica was also detected in the scales.

Calcium carbonate deposits from RRGE 1 fluid when the carbon dioxide is desolved; the solution was thought to be stable under other conditions. However, calcite deposits were found in and around a $30.5 \mathrm{~mm}$ (12 in.) ball valve as shown in Figure 5 . Calcite deposits were also found under the scales on the aluminum coupons. These observations suggest that the water is less stable with respect to calcite solubility than previously thought.

Other Surface Phenomena. Examination of the plain carbon steels revealed the presence of numerous very small tubercles; in this report these will be referred to as microtubercles. Such microtubercles were also found in other iron-base alloys such as the low alloy steels. The microtubercles were typically surrounded by small halos that appeared to be nearly free of corrosion, as shown in Figure 6 . These halos were thought to be localized cathodic areas that support the anodic pits under the microtubercles. X-ray fluorescence analysis of the halos 

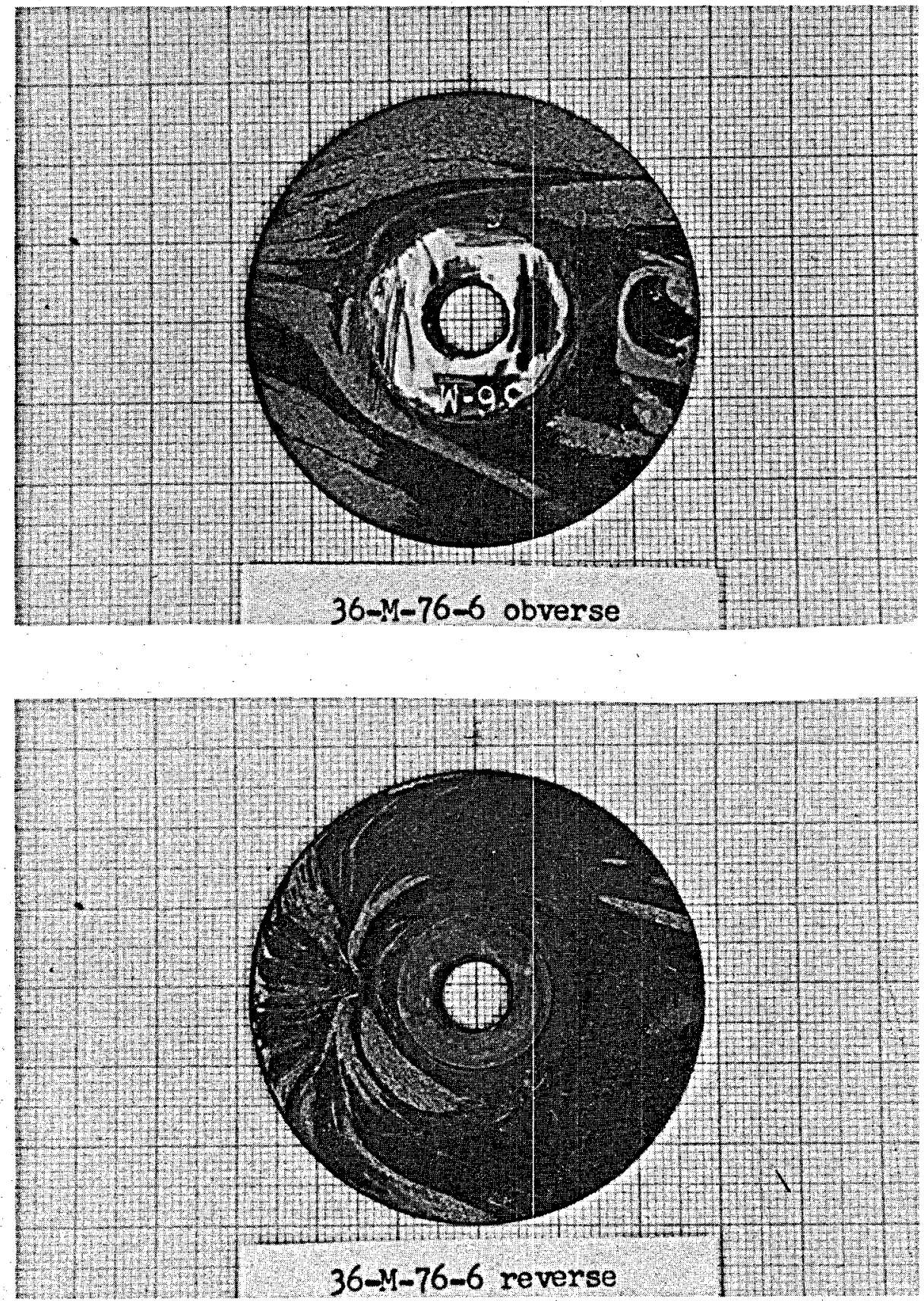

Fig. 4. Streaks of muscovite on coupon. Upper, obyerse side, and lower reverse side of Muntz metal coupon. Grid size is $1 \mathrm{~mm}$. 

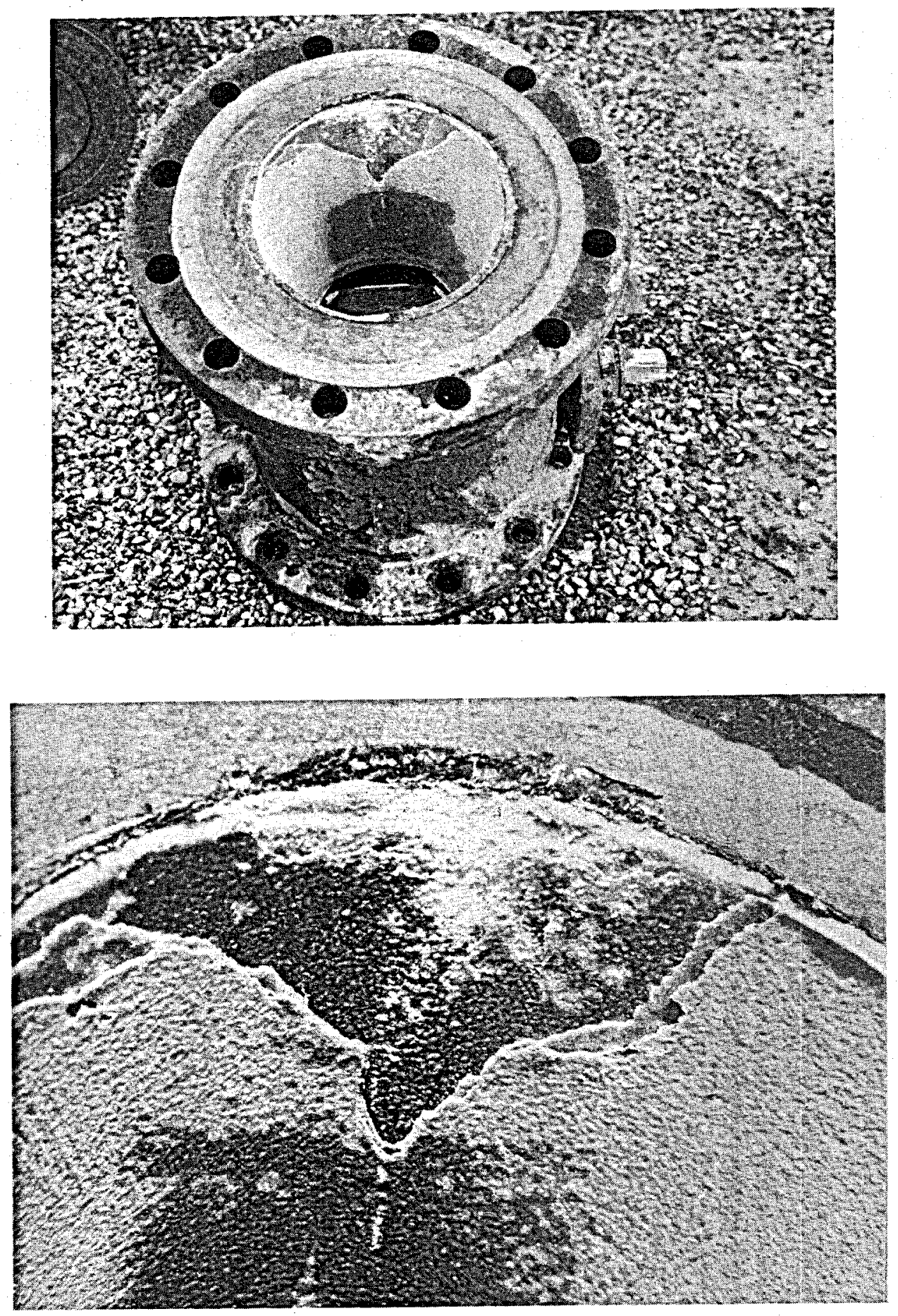

Fig. 5. Ball valve coated with calcite. Upper, overall view of valve; lower, close-up of scale. Scale thickness is about $2 \mathrm{~mm}$. 

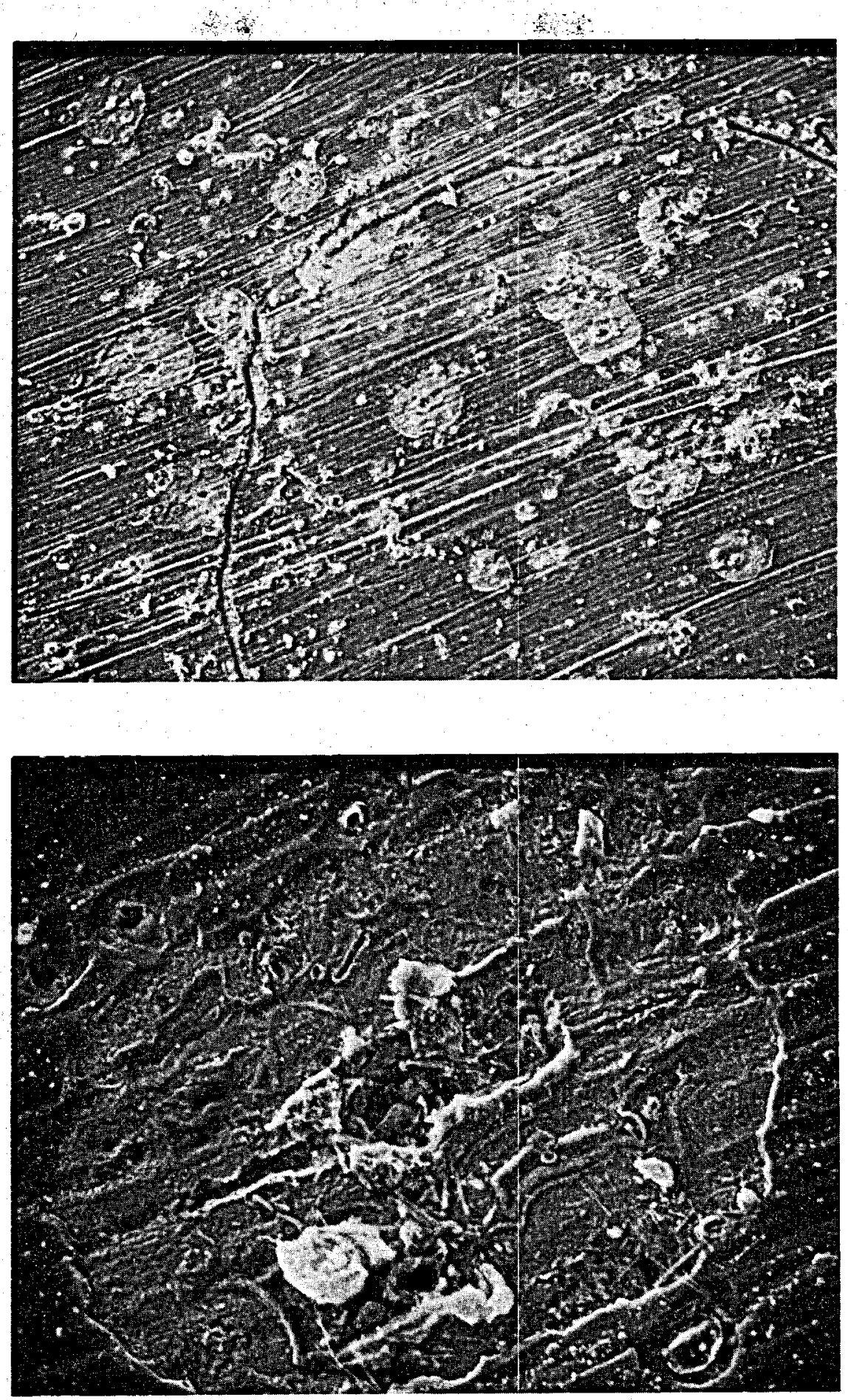

Fig. 6. Microtubercles. Upper, overall view of microtubercles on low-carbon steel coupon, magnification 56 diameters. Lower, close-up view of microtubercle and pit on low-carbon steel, magnification 560 diameters. 
showed that they contained a relatively large amount of silicon, presumably as silica. Microscopic examination of the coupons subsequent to cleaning showed that the halo areas were slightly more corroded than the areas outside of the halos. The pits in the microtubercles contained relatively large amounts of chlorides as determined by X-ray fluorescence analysis.

Weight Loss Data. As previously noted, weight loss data were not generally determined for coupons in this test; this was due, principal$1 y$, to the cost of cleaning the samples and because the data were felt to be less reliable than the short-term evaluation test data to be obtained in the next test series. However, weight loss data were taken . on the copper-nickel alloys and for Muntz metal. These data, given in Table IV, show a decrease in the average corrosion rate with time. This suggests that the corrosion product scales provided some protection from further corrosion.

\subsection{Discussion}

The results of the screening test suggest that the materials may be placed in acceptability classes as shown in Table $V$. Thus, the highmerit alloys, Haynes Alloy 6B, Hastelloy 6, and Inconel 625, gave the kind of performance one would expect. These materials were placed in Class 1 .

Aluminum bronze (nickel-free) and Muntz metal performed well and are placed in Class 2. These particular materials performed better than the alloys containing both copper and nickel.

Gray cast iron performed better than expected and was also placed in Class 2. The major uses of cast iron are in thick-member systems such as valves and fittings. The use of cast iron for heat exchanger heads is also anticipated. The plain carbon and low alloy steels performed about as expected they are in Class 4. 
CORROSION RATE* DATA FOR SELECTED MATERIALS

FROM THE SCREENING TEST

\begin{tabular}{|c|c|c|c|c|c|c|}
\hline \multirow{3}{*}{$\frac{\text { Material }}{\text { Muntz metal }}$} & \multicolumn{6}{|c|}{ Time } \\
\hline & \multicolumn{2}{|c|}{2 Weeks } & \multicolumn{2}{|c|}{6 Weeks } & \multicolumn{2}{|c|}{11 Weeks } \\
\hline & $\begin{array}{c}9.7 \\
(0.42)\end{array}$ & $\begin{array}{l}13.1 \\
(0.57)\end{array}$ & $\begin{array}{l}3.6 \\
(0.16)\end{array}$ & $\begin{array}{l}4.2 \\
(0.18)\end{array}$ & $\begin{array}{l}2.7 \\
(0.12)\end{array}$ & $\begin{array}{l}4.2 \\
(0.18)\end{array}$ \\
\hline Monel 400 & $\begin{array}{l}22.2 \\
(0.92)\end{array}$ & $\begin{array}{l}75.6 \\
(3.13)\end{array}$ & $\begin{array}{l}42.2 \\
(1.74)\end{array}$ & $\begin{array}{l}45.0 \\
(1.86)\end{array}$ & $\begin{array}{l}15.6 \\
(0.64)\end{array}$ & $\begin{array}{l}31.4 \\
(1.30)\end{array}$ \\
\hline $90 \mathrm{Cu} / 10 \mathrm{Ni}$ & $\begin{array}{c}157 \\
(6.41)\end{array}$ & $\begin{array}{l}186 \\
(7.59)\end{array}$ & $\begin{array}{l}58.0 \\
(2.37)\end{array}$ & $\begin{array}{l}85.7 \\
(3.50)\end{array}$ & $\begin{array}{l}45.8 \\
(1.87)\end{array}$ & $\begin{array}{l}66.2 \\
(2.70)\end{array}$ \\
\hline $70 \mathrm{Cu} / 10 \mathrm{Ni}$ & $\begin{array}{l}82.2 \\
(3.36)\end{array}$ & $\begin{array}{l}122 \\
(4.98)\end{array}$ & $\begin{array}{l}59.6 \\
(2.43)\end{array}$ & $\begin{array}{l}67.7 \\
(2.76)\end{array}$ & $\begin{array}{l}34.5 \\
(1.41)\end{array}$ & $\begin{array}{l}60.2 \\
(2.46)\end{array}$ \\
\hline
\end{tabular}




\section{TABLE $V$}

SUMMARY OF SCREENING TEST RESULTS ACCORDING TO ACCEPTABILITY CLASSES

\begin{tabular}{ll} 
Class 1. & Haynes Alloy 6B, Inconel 625, Hastelloy $G$ \\
Class 2. & $\begin{array}{l}\text { Gray cast iron, aluminum bronze (AMPCO 8, 12), } \\
\text { Muntz metal }\end{array}$ \\
Class 3. & None \\
Class 4. & $\begin{array}{l}\text { Mild stee1, low-carbon steel (ASTM A 515) } \\
9 \% \mathrm{Cr} \text { steel, Cor-Ten, AISI 4140, Monel 400 } \\
70 \mathrm{Cu} / 30 \mathrm{Ni}, 90 \mathrm{Cu} / 10 \mathrm{Ni}\end{array}$ \\
& 1100 aluminum, 5052 aluminum, 6061 aluminum \\
\hline
\end{tabular}


The aluminum alloys have been proposed as suitable materials for seawater desalination [30]. For this reason three grades of aluminum alloys were tested in the Raft River geothermal fluid. These materials performed very poorly and are placed in class 5 (unacceptable). These alloys showed severe erosion effects and corrosion. Aluminum relies on a refractory oxide surface for corrosion resistance, and the stability of the oxide is dependent on an oxidizing environment. The lack of an oxidizing environment (as indicated by the $+105 \mathrm{mV}$ potential) and the presence of trace amounts of hydrogen sulfide probably account for the observed behavior of these alloys. No further testing of aluminum alloys in unaerated geothermal fluid is anticipated. However, the use of these materials in cooling tower environments where aeration is provided will be investigated at a later date.

The alloys containing copper and nickel did not perform as well as expected in view of their wide use in seawater applications $[20,31,32]$. These materials showed localized corrosion and loss of nickel. The unexpected degradation of these alloys is attributed to reaction with the trace amount of hydrogen sulfide present in the water $(0.1 \mathrm{mg}$ $\mathrm{H}_{2} \mathrm{~S} / \mathrm{kg}$ water). Analysis of scale from the $70 \mathrm{Cu} / 30 \mathrm{Ni}$ and the Monel 400 showed that the scale was principally $\mathrm{Cu}_{5} \mathrm{FeS}_{4}$ (bornite) and $\mathrm{Ni}_{3} \mathrm{~S}_{2}$ (heazelwoodite). Weight loss data for these alloys are given in Table $V$. Because of the unexpected poor performance of these alloys additional tests are being conducted to confirm the results of our tests.

The presence of muscovite scales was unexpected and has ramifications beyond a scientific curiosity. The presence of large amounts of micaceous minerals on heat exchanger surfaces would materially degrade the heat transfer characteristics of such devices.

The conclusions drawn from these observations of the pits and surrounding halos are that the halos are cathodic relative to the pits but anodic relative to the areas beyond the halos. The pits are anodic relative to the halos and exhibit "classical" behavior in regard to increases in chloride concentration [14-17]. Muntz metal shows substantially better performance in the hot geothermal fluid than do any of 
the copper/nickel alloys. For example, Muntz metal is a factor of 2-5 times better at two weeks and 2-10 times better at eleven weeks than Monel 400, the best of the copper/nickel alloys, as shown in Figure 7. The copper/zinc phase diagram is shown in Figure $8^{[37]}$. The composition of Muntz metal, indicated on this diagram, is primarily alpha, but is near the alpha + beta phase boundary. Commercial alloys could possibly contain smal1 amounts of the beta phase. Two-phase alloys are typically more susceptible to corrosion than single-phase alloys of about the same composition. Additional tests of copper/zinc alloys at higher copper concentrations are in progress.

Among the copper/nickel alloys the corrosion rate increases with increasing copper content as shown in Figure 7. The copper/nickel phase diagram [37] shown in Figure 9 indicates that the system forms a continuous series of solid solutions over the entire range of compositions. Thus the presence of a second phase, which would promote corrosion, would not be expected. The copper/nickel alloys are typically more resistant to corrosion than the copper/zinc alloys in seawater service ${ }^{[32]}$; however, the opposite results were obtained in the RRGE 1 fluid.

The tendency of these alloys to corrode in seawater is shown in Figure $10^{[4]}$. The materials at the bottom left in this figure are the most corrosion-resistant, while the least corrosion-resistant materials are at the top right. The results obtained in the screening test are at variance with those one would expect if the seawater data offered a good model for the Raft River fluids.

On the basis of these results the accelerated corrosion of the copper/nickel alloys, as compared with Muntz metal, must be attributed to two factors:

1. The hydrogen sulfide content of the geothermal fluid.

2. The susceptibility of nickel to suifide attack.

The effects of variations in temperature of the geothermal fluid have not been investigated. However, prel iminary indications suggest 


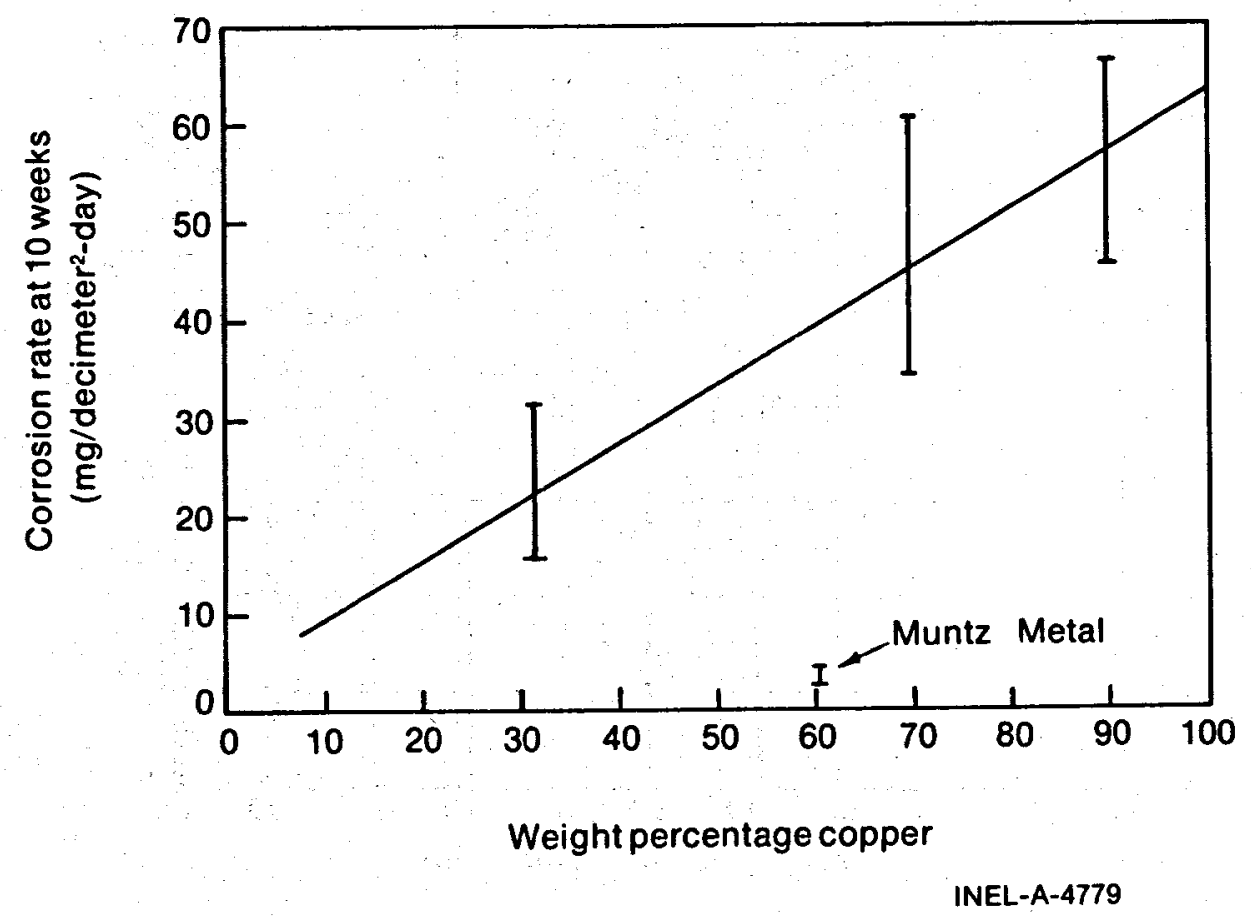

Fig. 7. Corrosion rate as a function of copper content for several copper alloys. 


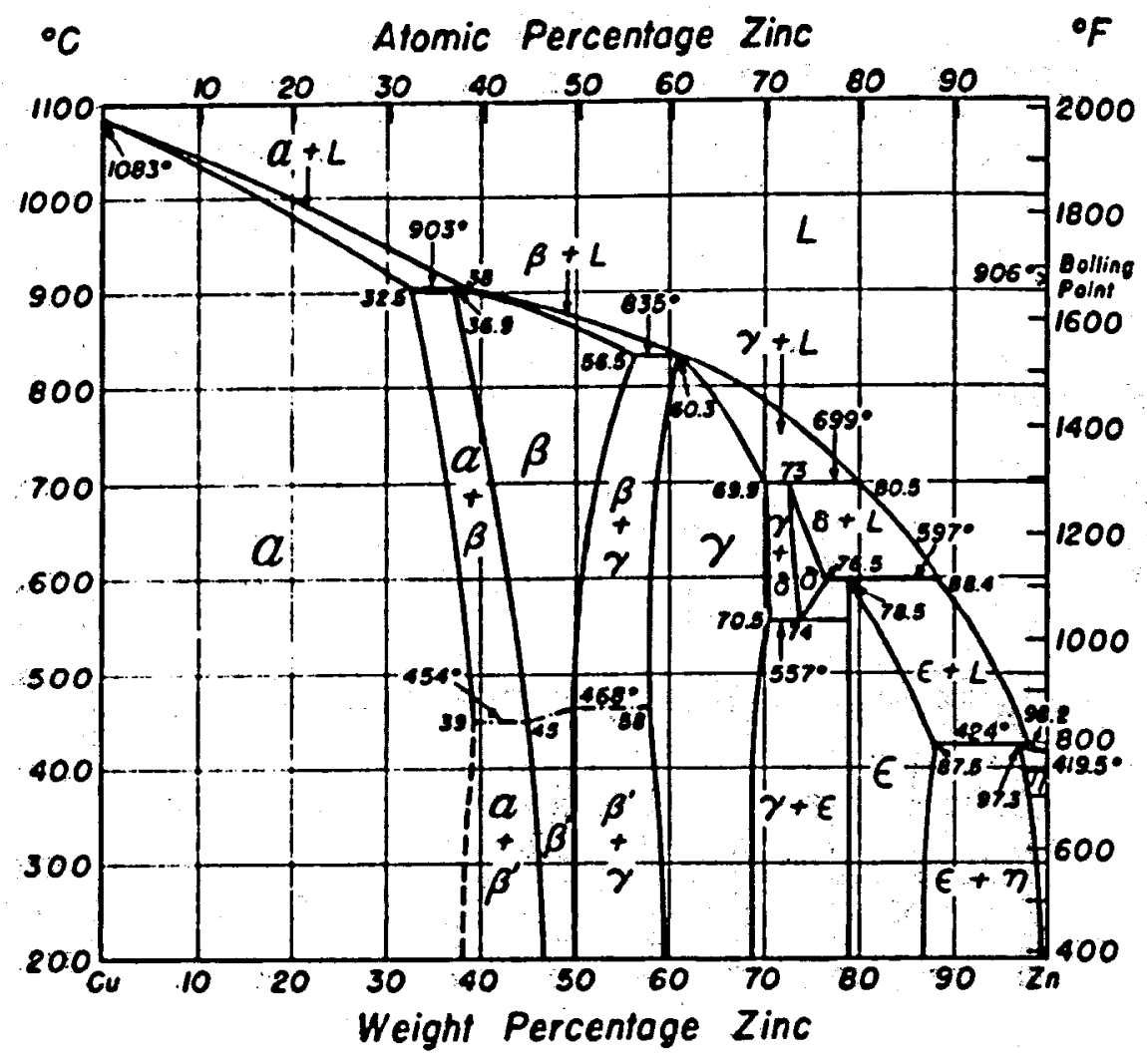

Fig. 8. Copper/zinc phase diagram (37).

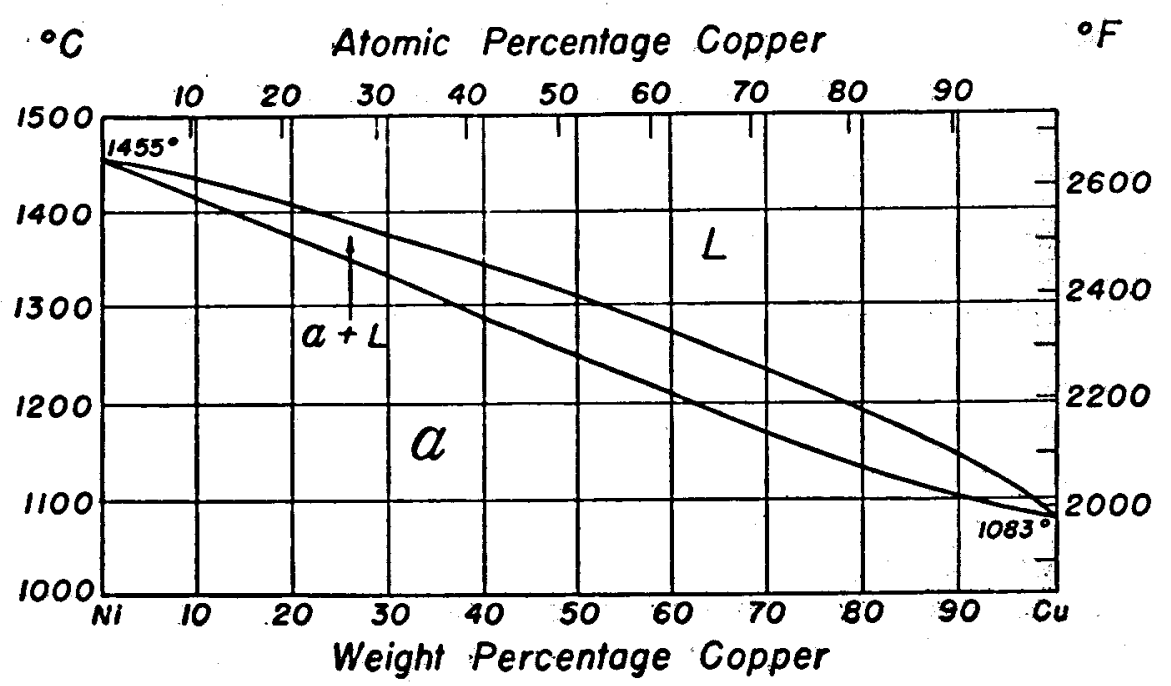

Fig. 9. Copper/nickel phase diagram (37). 
VOLTS: SATURATED CALOMEL HALF-CELL REFERENCE ELECTRODE


Alloys are listed in the order of the potential they exhibit in flowing sea water. Certain alloys indicated by the symbol: in low-velocity or poorly aerated water, and at shielded areas, may become active and exhibit a potential near -0.5 volts.

Fig. 10. Electrochemical potentials for several materials

in flowing seawater (4). Flow velocity 2.4 to $4 \mathrm{~m} / \mathrm{s}$ ( 8 to $13 \mathrm{f} / \mathrm{s}$ ), temperature, 10 to $27^{\circ} \mathrm{C}\left(50\right.$ to $\left.80^{\circ} \mathrm{F}\right)$. 
that corrosion rates increase with temperature, as would be expected ${ }^{[1]}$. Both thermodynamics and kinetics must be considered when evaluating chemical reactions, and a more complete understanding of these aspects of corrosion might enable us to account for the observed behavior of the copper/nickel alloys. Additional studies are planned to more fully define the role of each of these factors in the corrosion of copper/nickel alloys in Raft River geothermal fluid.

\section{SHORT-TERM MATERIALS EVALUATION TESTS}

The test data reported here are for the first of several short-term (about 100 days) evaluation tests. The tests are conducted in two 102-mm (4-in. Sch. 40 pipe) flow lines on the Mobile Components-Test Trailer. These tests provide corrosion rate data an a number of materials in the hot geothermal fluid. The corrosion data include pit depth measurements where applicable. The results of these tests have provided more reliable and accurate design data on corrosion rates than were available from the screening tests, and also some indication of the reliability and sensitivity of our test procedures.

\subsection{Test Location}

A Mobile Components-Test Trailer was designed and fabricated to provide support capability for a number of test programs, such as:

1. Corrosion and scaling of materials.

2. Shell-and-tube heat exchanger fouling.

3. Flashing heat exchanger test.

4. Fluidized-bed heat exchanger design and testing.

The corrosion and scaling flow lines were utilized for the shortterm evaluation tests reported here. The flow lines are 102-mm (4-in. Sch. 40 ) pipes divided into two $1.2-\mathrm{m}(4-\mathrm{ft})$ test sections. A 1.2-m $(4-f t)$ section ahead of the flow, temperature, and pressure transducers provides a stabilizing region, originally intended as a water chemistry modification or materials-test section. Experience has indicated the 
need for a flow stabilization section and this section is now reserved for this purpose. The configuration of the two flow lines does not allow for recirculation; however, the lines may be operated in parallel or in series. An overall view of the Mobile Components-Test Trailer is shown in Figure 11.

\subsection{Environment}

The geothermal fluid used in this test was from RRGE 1 and is described in Table I. The nominal temperature of the fluid was $133^{\circ} \mathrm{C}$ $\left(272^{\circ} \mathrm{F}\right)$.

Samples for the short-term evaluation tests were located in three of the four available test sections, on the Mobile Components-Test Trailer. The fourth section was replaced with a spool piece supplied by Brookhaven National Laboratory ${ }^{[a]}$. The test sections were connected in series. Flow was maintained at about $1.5 \mathrm{~m} / \mathrm{s}(5 \mathrm{ft} / \mathrm{s})$ during the experiment.

\subsection{Materials}

The rationale for testing plain carbon and low alloy steels was set forth in Section III, 1.3. As noted in that section, these materials are the least expensive in terms of initial cost and have been used as a baseline for evaluating the cost of construction of the Thermal Loop Facility. The plain carbon and low alloy steels were retested in this short-term test. The nominal compositions of these materials are given in Table A-IV.

Stainless steels have a tendency towards severe localized corrosion (for example, crevice corrosion, pitting, and stress corrosion cracking) in seawater if proper conditions are not maintained in the system. For

[a] This spool piece contains samples of polymer concrete and polymerimpregnated concrete being evaluated for possible applications in geothermal service. These additional tests are being conducted as part of our cooperative effort with other National Laboratories and vendors involved in materials for geothermal applications. 




$C, \ldots$, 
this reason they were not tested in the screening test. An economic evaluation of several construction materials for the Thermal Loop Facility suggested that AISI 316 stainless steel was about the upper limit in terms of materials cost; for this reason several stainless steels were selected for testing. Allegheny-Ludlum recommended a number of their alloys for geothermal fluid service ${ }^{[38]}$, and four were tested as part of our policy of assisting industry in evaluation of materials for geothermal service.

Stainless steel has fewer applications in seawater service than does carbon steel. Peterson and Lennox ${ }^{[35]}$ noted that "...successful designs usually may be categorized into one of two classes: (1) the stainless steel is intentionally or inadvertently provided with cathodic protection, (2) the stainless steel is immersed in seawater with a continuous flow velocity of at least six $\mathrm{ft} / \mathrm{sec} . "$ The passivity of stainless steels is due to stable oxide films that retard corrosion. The stability of these materials is thus predicated on the presence of an oxidizing environment. The depletion of oxidant, as in a crevice or under debris, usually leads to pitting. This pitting, once initiated, does not heal by the formation of a new oxide layer and thus does not tend to decrease with time ${ }^{[39]}$. The absence of oxygen in the Raft River geothermal fluid, as indicated by its electrochemical potential (+ $105 \mathrm{mv}$ versus SHE) would lead one to be cautious in selection of stainless steels for use in the Raft River facilities. However, the cost of AISI 316 stainless steel is about the maximum that can be tolerated in design of the Thermal Loop Facility and primarily on this basis the alloy was selected for testing. AISI 410 stainless steel is very susceptible to pitting and crevice corrosion ${ }^{[35]}$; however, it is a common pump shaft material and was tested for this reason. The precipitation hardening alloys such as 17-4PH are frequently used in valves. This material will be evaluated in future tests. The compositions of these materials are given in Table A-IV.

Three aluminum bronzes were tested because of their potential use in pumps. These materials were supplied by AMPCO, of Milwaukee, Wis. The compositions of these materials are given in Table A-III. 
Titanium was tested to help complete the picture with respect to materials performance $[40,41]$. There have been suggestions that titanium suffers from crevice corrosion at about $149^{\circ} \mathrm{C}\left(300^{\circ} \mathrm{F}\right)$, just above the maximum temperature we will encounter in our studies. Another titanium alloy, ASTM A265, Grade 12, (TiCode 12), will be tested in another short-term evaluation test ${ }^{[42]}$. The nominal compositions of titanium and TiCode 12 are noted in Table A-VI.

\subsection{Test: Assembly}

The configurations of the coupons and the TFE insulating washers and tubes are the same as those used in the screening test, shown in Figure 2. The mounting spool was similar to that used in the screening test, differing only in the larger dimensions of the centering cruciform required for the $10-\mathrm{cm}$ flow 1 ine (4-in. Sch. 40 pipe) used in the present test.

\subsection{Planned:Interval Test Schedule}

The need for materials test data for procurement purposes increased: the priority for well usage for materials testing. The first short-term test was started August 25, 1976. Flow was stopped for 11 days to repair a transfer line, otherwise the test went essentially according to schedule.

In this test the "Planned Interval Test"[25, 28, 29] 'was used; samples were removed at 33,70 and 109 days. Additional samples were inserted into the test section for the final 39 days:

The planned interval test schedule offers interesting possibilities for interpretation of corrosion test data. This technique requires four coupons (with replication, additional coupons would be used) of each material to be tested. The schedule for inserting and removing coupons is shown in Figure 12.

In the planned interval test those variables that can be controlled are held constant for the duration of the test, i.e., from the start of 


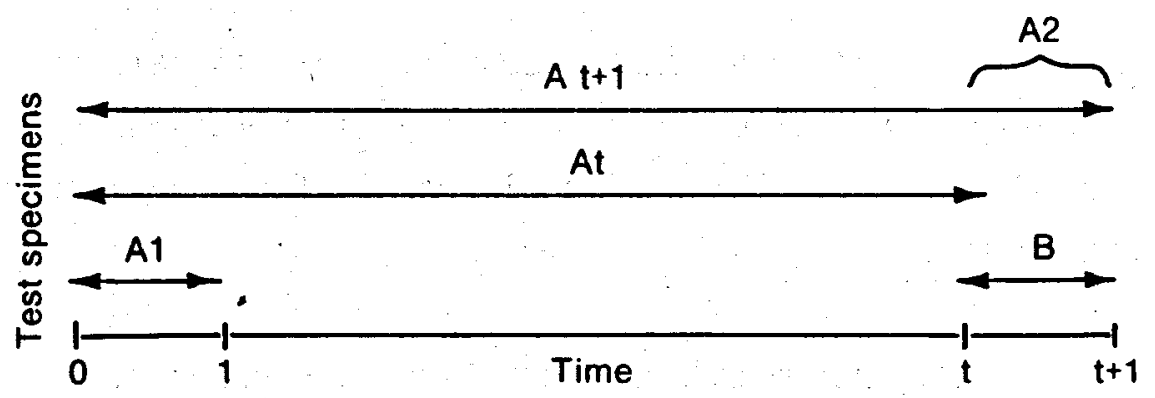

Identical specimens all placed in the same corrosive fluid. Imposed conditions of the test kept constant for entire time $t+1$. Letters, A1, At, $A t+1, B$, represent corrosion damage experienced by each test specimen. $A 2$ is calculated by subtracting At from $A t+1$.

INEL-A-4780

Fig. 12. Schedule for conducting planned interval test. 
coupon exposure to time $=t+1$. Corrosion rates and associated damage are denoted by $A_{1}, A_{t}, A_{t}+1$, and $B$. The corrosion rate $A_{2}$ is the difference between $A_{t}+1$ and $A_{t}$. In our experiments we have little or no control over wellhead temperature or the composition of the geothermal fluid. Changes in either of these variables would contribute to changes in the aggressiveness of the environment. Three criteria may be used to judge whether or not changes have occurred:

1. If $A_{1}=B$, then geothermal fluid corrosiveness is unchanged.

2. If $B<A_{1}$, then geothermal fluid corrosiveness decreases.

3. If $A_{1}<B$, geothermal fluid corrosiveness increases.

Scales of corrosion products or deposition of minerals from the geothermal fluid on the corrosion coupons may alter the response of the metal to the environment. Three criteria result from consideration of metal corrodibility.

1. If $A_{2}=B$, then metal corrodibility is unchanged.

2. If $A_{2}<B$, then metal corrodibility decreases.

3. If $B<A_{2}$, then metal corrodibitity increases.

Comparison of weight loss data in the context of the foregoing criteria will suggest changes in the aggressiveness of the geothermal fluid with time or changes in the resistance of the metal to the geothermal fluid environment. The criteria associated with the various combinations of corrosiveness and corrodibility are given in Table VI. The weight loss data from these short-term tests will be analyzed using the criteria in this table.

\subsection{Results}

Prior to cleaning for weight loss determination, a visual : examination of each corrosion coupon was performed. Subsequent to cleaning, the weight loss of each coupon was determined and a second visual examination was made to determine pit depths. The results of these observations. and measurements are given in Table VII: The acceptabjlity classes in this table are the same as in Table III and reflect the interpretation 
TABLE VI

CORROSIVENESS, CORRODIBILITY, AND WEIGHT LOSS CRITERIA [25]

Criteria

Metal Corrodibility

Liquid Corrosiveness

$A_{1}=A_{2}=B$

unchanged

unchanged

$A_{2}<A_{1}=B$

decreased

unchanged

$A_{1}=B<A_{2}$

increased

unchanged

$A_{2}=B<A_{1}$

unchanged

decreased

$A_{2}<B<A_{1}$

decreased

decreased

$A_{1}>B<A_{2}$

increased

decreased

$A_{1}<A_{2}=B$

unchanged

increased

$A_{1}<B>A_{2}$

decreased

increased

$A_{1}<B<A_{2}$

increased

increased 
TABLE VII

RESULTS OF SHORT-TERM MATERIALS EVALUATION TESTS

\begin{tabular}{|c|c|}
\hline MATERIAL & OBSERVATIONS \\
\hline $\begin{array}{l}\text { All legheny-Ludlum } \\
29-4-2\end{array}$ & $\begin{array}{l}\text { Yellowish to light gray discoloration at } 33 \text { days. } \\
\text { Becomes a gray-green color at } 109 \text { days. Few scattered } \\
\text { black microtubercle-like deposits at } 70 \text { days. No } \\
\text { evidence of corrosion. }\end{array}$ \\
\hline $\begin{array}{l}\text { Al legheny-Ludlum } \\
29-4\end{array}$ & $\begin{array}{l}\text { General yellow to gray discoloration at } 33 \text { days, } \\
\text { becomes darker with time. Scattered black micro- } \\
\text { tubercle-like deposits at } 70 \text { days. Pitting and general } \\
\text { corrosion, if any, is of the same magnitude as the } \\
\text { surface roughness. Some minor indications of crevice } \\
\text { corrosion under beveled edge of TFE washer at } 109 \text { days. }\end{array}$ \\
\hline Inconel 625 & $\begin{array}{l}\text { Very light yellow film observed at } 33 \text { days, darkens to } \\
\text { gray at } 109 \text { days. Scale is variable in thickness but } \\
\text { easily scrubbed off. Halo-like areas of possible } \\
\text { corrosion products observed at } 70 \text { days, some with } \\
\text { black microtubercles in center. Pitting, if any, is of } \\
\text { same magnitude as surface roughness. }\end{array}$ \\
\hline
\end{tabular}

Haynes 6B $\quad$ Very light gray discoloration at 33 days, becomes gray-green at 109:days. Severa] halo-1ike areas may be indications of localized corrosion. Corrosion, including pitting, if any, is of same magnitude as surface roughness.

Titanium

(ASTM B 265

Grade 12)

Allegheny-Ludlum 216

Light yellow to gray-brown scaling at 33 days, darkens with time. A few scattered black tubercles observed at 70 days. Very shallow pitting under tubercles, no crevice corrosion observed under TFE washer.

Very slight tarnish at 33 days, becoming greenish-gray at 70 days and yellow-brown-gray at 109 days:

Scattered halos of corrosion products with pitting of the order of the surface roughness of the materials at 33 days. At long times the pits deepen. One pit under the beveled edge of the TFE washer suggests crevice corrosion but may be due to pitting.

Allegheny-Ludlum Very thin, loose yellow-to-gray film at 33 days, darkens $6 \mathrm{X}$ with time to become yellow-green to brown at 70 days and more gray at 109 days. Scattered halo-like areas may be indications of pit nucleation. One pit identified at end of last 39-day test period with pit being slightly deeper than surface roughness. Other pits, if any, are of the same magnitude as the surface roughness. 


\begin{tabular}{|c|c|}
\hline MATERIAL & OBSERVATIONS \\
\hline Hastelloy $G$ & $\begin{array}{l}\text { Very light yellow discoloration at } 33 \text { days, becomes } \\
\text { light gray at } 109 \text { days. No corrosion observed in } \\
\text { first } 33 \text {-day period, one sma } 11 \text { pit observed at end of } \\
\text { last } 39 \text {-day test period. A few scattered pits } \\
\text { identified at } 70 \text { days, one somewhat deeper than others. }\end{array}$ \\
\hline $\begin{array}{l}\text { AMPCO } 8 \\
\text { (A)uminum bronz }\end{array}$ & $\begin{array}{l}\text { Purple-black scale at end of first } 33 \text { days. At } 109 \text { days } \\
\text { scales appear to be dense and nonadherent. They are } \\
\text { stacks of hexagonal-tabular crystals. Purple and } \\
\text { green scales and scattered calcite deposits at end of } \\
\text { last } 39 \text {-day test period. Some calcite deposits noted } \\
\text { under beveled edge of TFE washer and in occluded region } \\
\text { between washer and TFE tube. Dealloying under washer; } \\
\text { except for black corrosion products there is little } \\
\text { evidence of corrosion elsewhere. }\end{array}$ \\
\hline
\end{tabular}

AISI 316 Stainless Steel

AMPCO 12

(Aluminum bronze, casting alloy)

AMPCO 483

(Aluminum bronze, with nickel)

AISI 304 Stainless Steel

Mild Steel (AISI 1018)
Slight yellow tarnish at 33 days, becomes yellow-gray in 109 days. Halo-like areas of corrosion products around microtubercles. Microtubercles overlie small pits. Pitting is significantly less than for 304 stainless steel. Some crevice corrosion seen in last 39-day test period, with one large pit found near beveled edge of TFE washer.

Purple-black scale at end of first 33-day test period, scale is generally dense and black at 109 days. At end of last 39 days scale is generally purple with areas of green scale and small yellow crust-like spots. Sma17, broad pits under crust. Slight dealloying under TFE washer.

Areas of black, purple and yellow scales at 33 days, black scale underlies yellow areas. Black scale is generally tightly adherent and overlies localized corrosion. Scattered calcite crystals under beveled edge of TFE washer. Slight dealloying under TFE washer, also some pitting observed under washer.

Overall yellow discoloration on unprotected areas at end of 33-day test period, yellow-green at 70 days and yellow to brown to gray at 109 days. Numerous halo-like areas with tubercles overlying pits in halos. Crevice corrosion near beveled edge of TFE washer and under washer.

Areas of nonadherent yellow and black scale overlying tight black scale in first 33 days. In last 39 days there were areas of iridescent brown and black scales; scales did not effervesce with dilute $\mathrm{HCl}$. At 70 days one side of coupon has scales that are predominantly yellow, other side is predominantly black. At 109 days the differentiation between sides 
TABLE VII (Contd)

MATERIAL

Low-carbon steel

(ASTM A515)

9\% Chromium stee]

(ASTM A182,

Grade: F9)

Cor-Ten

(High-strength,

low alloy steel)

Gray cast iron

Low alloy steel

(AISI 4140)
OBSERVATIONS

is not as great as at 70 days; areas of yellow, green, black and rust-red scales overlying a gray scale. There is general pitting, shallow and broad, underlying the scales. Some halo-like areas of immunity at 33 days, less apparent at longer times. Some microtubercles in the halos, overlying pits at 33 days. Slight crevice corrosion.

Areas of blue iridescent film and thin black scale. Many small yellow spots, at end of first 33-day and last 39-day test periods. At 70 days areas of yellow and black scales are apparent with rust-red microtubercles. At 109 days there are areas of green scale in addition to the yellow and black scales. Areas of shallow, broad localized corrosion at end of first 33-day test period. Small pits underlying rust-red microtubercles at longer time.

B lack discoloration at end of 33 days, some areas of iridescent purple film, brown iridescent film at 109 days. Yellow microtubercles at 109 days. Machining or rolling marks broadened and deepened at al1 times, deep pits at 70 and 109 days. Deep crevice corrosion at 70 and 109 days.

Areas of iridescent blue-purple and black films at end of first 33 days and last 39 days; also, some loose yellow scale and areas of rust-red scale. At end of 70 days the reverse side has yellow-to-greento-gray deposit, obverse side had black deposit. Differences in sides less pronounced at 109 days. Numerous small pits underlying scales, some with black microtubercles.

At end of first 33-day test period a yellow: scale overlies a nonadherent gray scale. At end of last 39-day test period, areas of black and brown scale; the black scale appears to be thicker than the brown scale. No extensive corrosion at end of first 33 days of exposure, at end of last 39-day period there are small areas of yellow scale overlying pits. Pitting is more general at end of $70-$ and109-day test periods. Corrosion is not severe.

At 33 days, areas of iridescent blue-purple to black films. Crusts of white-brown material overlying pits and general corrosion. Some halo-like areas surrounding pits. At longer times green-gray deposits and green-yellow deposits. Numerous microtubercles overlying pits of varying depth and breadth. 
TABLE VII (Contd)

MATERIAL

AISI 410

Stainless Steel

AISI 440

Stainless Stee]

\section{OBSERVATIONS}

Thin iridescent brown film over total surface area at 33 days. Numerous gray and yellow-brown microtubercles overlying pits. Pits are narrow and deep. Severe crevice corrosion near beveled edge of TFE washer.

Iridescent blue and brown films at end of 33-day and 39-day test periods, films darken to black with time. Scattered deep pits beneath corrosion products in and around pits. Pits tend to extend in direction of machining or rolling marks. Severe crevice corrosion at end of first 33 days but less at end of last 39-day test period. Crevice corrosion is severe at 70 and 109 days. 
of visual examinations and corrosion rate measurements. Weight loss data for materials exposed to the geothermal fluid during the planned interval test are collected in Table VIII. A data analysis, based on the criteria established for the planned interval test, is also included in this table. Table VI sets forth these criteria and the associated conclusions.

Some samples were pitted or exhibited crevice corrosion. Subsequent to cleaning, the pitted samples were examined to determine the depth of the deepest pits. A Bausch and Lomb monocular metallurgical microscope was used to make these measurements. This microscope had a fine focus adjustment graduated in $0.002-\mathrm{mm}$ divisions. The technique was to first focus on the bottom of the pit, then elevate the tube, using the fine adjustment to focus in the relatively less corroded area adjacent to the pit. The process was repeated at least one time to avaid gross errors in measurement. The pits were generally too narrow to accommodate a needle type probe.

The results of pit depth measurements are included in Table VIII. The data related to pit depths are separated according to location. Thus, the pits associated with the TFE washer, i.e., crevice corrosion pits, are listed under crevice corrosion. Pits in nonoccluded areas of the coupons are listed under pitting. In both cases pit depths are given in millimeters.

\subsection{Discussion and Conclusions}

In this test more high-merit alloys were evaluated than in the screening test. Additional corrosion-resistant materials will be examined in other short-term tests to provide a spectrum of response of materials from several generic classes to the Raft River geothermal fluid. Of the materials used in the present test, the Allegheny-Ludlum alloys designated 29-4 and 29-4-2 gave superior performance, as did Inconel 625, Haynes Alloy 6B, and titanium (ASTM B265, Grade 12). These materials are in Class 1. Allegheny-Ludlum alloys 216 and $6 \mathrm{X}$ are marginally in Class 1 but might be better in Class 2. Hastelloy $G$ and the nickel-free aluminum bronze, AMPCO 8, are in Class 2. 


\section{TABLE VIII}

WEIGHT LOSS DATA FROH PLANMED INTERVAL TESTS

\begin{tabular}{|c|c|c|c|c|c|c|c|}
\hline Alloy & $\begin{array}{l}\text { Loss } \\
\text { Units* }\end{array}$ & $A_{1}$ & B & $A_{2}$ & $A_{t}$ & $A_{t+1}$ & Remarks \\
\hline Allegheny-Ludlum 29-4-2 & mdd & $\begin{array}{l}0.01 \\
4.5 \times 10^{-5}\end{array}$ & $\frac{0.06}{2.7} \times 10^{-4}$ & $\stackrel{0.02}{9.00} \times 10^{-5}$ & $\begin{array}{l}0 \\
0\end{array}$ & $\begin{array}{l}0.02 \\
9.0\end{array} \times 10^{-5}$ & $\begin{array}{l}\text { Data indicate that the corrosivity of } \\
\text { the geothermal fludd has increased and } \\
\text { metal corrodibility has decreased. } \\
\text { These data are probably within the } \\
\text { mannitude of the experimental error of } \\
\text { the procedure. }\end{array}$ \\
\hline
\end{tabular}

Al legheny-Ludlum 29-4

$\underset{m+A}{m / A} \quad 0$

Inconel 625

은
Haynes 6B

Timet Titanium

ASTM B 265, Grade ?

\begin{abstract}
Allegheny-Ludlum 276
Crevice Corrosion Pitting
\end{abstract}

Al legheny-Ludl um $6 x$

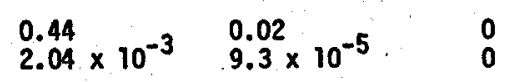

\section{$9.3 \times 10^{-5}$}

Data indicate that the corrosivity of the geothermal fluid has increased and the metal corrodibility has decreased. These data are probabiy within the magnitude of the experimental error of the procedure.

This alloy did not show evidence of corrosion.

\begin{tabular}{|c|c|c|c|c|c|}
\hline $\mathrm{mod}_{\mathrm{mm} / \mathrm{A}}$ & $\begin{array}{l}0 \\
0\end{array}$ & $\begin{array}{l}0 \\
0\end{array}$ & $\begin{array}{l}0 \\
0\end{array}$ & $\begin{array}{l}\mathbf{0} \\
\mathbf{0}\end{array}$ & $\begin{array}{l}0 \\
0\end{array}$ \\
\hline $\begin{array}{l}\text { modd } \\
\mathrm{mm} / \mathrm{A}\end{array}$ & $\begin{array}{l}0.25 \\
1.3 \times 10^{-3}\end{array}$ & $\begin{array}{l}0.29 \\
1.3 \times 10^{-3}\end{array}$ & $0.1 \times 10^{-4}$ & $\begin{array}{l}0 \\
0\end{array}$ & $\begin{array}{l}0.1 \\
4.4\end{array} \times 10^{-4}$ \\
\hline
\end{tabular}

Data indicate that liquid corrosivity is unchanged and the corrodibility of the metal has decreased. This is a very corrosion-resistant alloy and the data probably fall within the magnitude of the experimental error for the experiment.

Data Indicate that the riquid corrosivity has increased and metal corrodibility has decreased. This is very corrosion-resistant alloy and the data are probably within the error of measurement for the equipment.

Data indicate the corrosivity of the geothermal fluid has increased and the metal corrodibility has decreased. This is a very corrosion-resistant alloy and the data are probably within the error of measurement for the experiment.

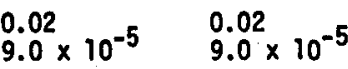

This is a very corrosion-resistant

alloy; except for one pit there is insufficient corrosion damage to judge changes in the corrosiveness of the geothermal fluid or the change in metal corrodibility. 


\begin{tabular}{|c|c|c|c|c|c|c|}
\hline Alloy & $\begin{array}{l}\text { Loss } \\
\text { Units* }\end{array}$ & $A_{1}$ & B & $A_{2}$ & $A_{t}$ & $A_{t+1}$ \\
\hline Hastelloy G & $\begin{array}{l}\mathrm{mdd} \\
\mathrm{mm} / \mathrm{A}\end{array}$ & $\begin{array}{l}0.15 \\
6.6 \times 10^{-4}\end{array}$ & $0.13 \times 10^{-4}$ & $\begin{array}{l}-0.03 \\
-1.3 \times 10^{-4}\end{array}$ & $\begin{array}{l}0.05 \\
2.2 \times 10^{-4}\end{array}$ & $\begin{array}{l}0.02 \\
8.8 \times 10^{-5}\end{array}$ \\
\hline $\begin{array}{l}\text { AMPCO } 8 \\
\text { (Aluminum bronze) }\end{array}$ & $\begin{array}{l}\text { mdd } \\
\mathrm{mm} / \mathrm{A}\end{array}$ & $\frac{26.7}{1.23} \times 10^{-1}$ & $\begin{array}{l}41.4 \\
1.90 \times 10^{-1}\end{array}$ & $\begin{array}{l}5.0 \\
2.3 \times 10^{-2}\end{array}$ & $\begin{array}{l}16.6 \\
7.63 \times 10^{-2}\end{array}$ & $\begin{array}{l}21.6 \\
9.9 \times 10^{-2}\end{array}$ \\
\hline AISI 316 Stainless Steel & $\begin{array}{l}\mathrm{mdd} \\
\mathrm{mm} / \mathrm{A}\end{array}$ & $0.23 \times 10^{-3}$ & $\begin{array}{l}0.13 \\
5.9 \times 10^{-4}\end{array}$ & $2.7 \times 10^{-4}$ & $\begin{array}{l}0.12 \\
5.5 \times 10^{-4}\end{array}$ & $\begin{array}{l}0.06 \\
2.7 \times 10^{-4}\end{array}$ \\
\hline $\begin{array}{l}\text { Crevice Corrosion } \\
\text { Pitting }\end{array}$ & $\begin{array}{l}\mathrm{mm} \\
\mathrm{mm}\end{array}$ & $\overline{0.02}$ & 0.02 & --- & $\overline{0.028}$ & $\overline{0.04}$ \\
\hline AMPCO 12 & $\begin{array}{l}\mathrm{mdd} \\
\mathrm{mm} / \mathrm{A}\end{array}$ & $\frac{28.8}{1.4} \times 10^{-4}$ & $\begin{array}{l}4.1 \\
2.0 \times 10^{-2}\end{array}$ & $6.3 \times 10^{-2}$ & $\begin{array}{l}27.3 \\
1.3 \times 10^{-1}\end{array}$ & $\begin{array}{l}40.5 \\
1.9 \times 10^{-1}\end{array}$ \\
\hline $\begin{array}{l}\text { Crevice Corrosion } \\
\text { Pitting }\end{array}$ & $\operatorname{mim}_{\mathrm{mm}}$ & $<0.02$ & $\overline{0.03}$ & --- & $\overline{0.04}$ & $\begin{array}{l}0.06 \\
0.04\end{array}$ \\
\hline AMPCO 483 & $\begin{array}{l}\mathrm{mdd} \\
\mathrm{mm} / \mathrm{A}\end{array}$ & $\begin{array}{l}103 \\
4.9\end{array} \times 10^{-1}$ & $\begin{array}{l}108 \\
5.2 \times 10^{-1}\end{array}$ & $\frac{-5}{2.4} \times 10^{-2}$ & $\frac{58}{2.8} \times 10^{-1}$ & $\begin{array}{l}53 \\
2.5 \times 10^{-1}\end{array}$ \\
\hline $\begin{array}{l}\text { Crevice Corrosion } \\
\text { Pitting }\end{array}$ & $\underset{m m}{m m}$ & $\overline{0.28}$ & 0.06 & --- & $\begin{array}{l}0.05 \\
0.05\end{array}$ & $\overline{0.23}$ \\
\hline AISI 304 Stainiess Steel & $\begin{array}{l}\mathrm{mdd} \\
\mathrm{mm} / \mathrm{A}\end{array}$ & $\stackrel{0.3}{1.4} \times 10^{-3}$ & $\begin{array}{l}0 \\
0\end{array}$ & $\begin{array}{l}-0.04 \\
-1.8 \times 10^{-4}\end{array}$ & $\begin{array}{l}0.15 \\
6.8 \times 10^{-4}\end{array}$ & $\begin{array}{l}0.11 \\
5.0 \times 10^{-4}\end{array}$ \\
\hline $\begin{array}{l}\text { Crevice Corrosion } \\
\text { Pitting }\end{array}$ & $\frac{\mathrm{mm}}{\mathrm{mm}}$ & slight & $\overline{0.06}$ & --- & S1fght & $\overline{0.23}$ \\
\hline
\end{tabular}

Mild Steel (AISI 1018)

Crevice Corrosion Pitting

$\begin{array}{ll}\mathrm{mm} / \mathrm{A} & 13.7 \\ \mathrm{~mm} / \mathrm{A} & 6.9 \times 10^{-2} \\ \mathrm{mdd} & 6.8 \\ \mathrm{~mm} / \mathrm{A} & 3.4 \times 10^{-2} \\ \mathrm{~mm} & 0.04\end{array}$

mm

0.04
0.10
9.7
$4.9 \times 10^{-2}$
$9.3 \times 10^{-2}$
$4.7 \times 1$

0.02
0.04
$1.3 \times 10^{-2}$

$1^{-2.1} i^{1} \times 10^{-2}$

$--$
$5.6 \times 10^{-2}$

$11.0 \times 10^{-2}$

0.18
0.076
$8.7 \times 10^{-2}$

$8.9 \times 10^{-2}$

0.076

Remarks

Data indicate that the corrosivity

of the geothermal fluid has increased

and the metal corrodibility has

decreased. These data are probably

whin the magnitude of error for

the experiment.

Data fndicate that the corrosivity

of the geothermal fluid has increased and the metal corrodibility has decreased.

The data indicate that the corrosivity of the geothermal fluid has decreased as has the metal corrodibility. However, this is a corrosion-resistant metal and most of the observed corrosion was localized as pitting and crevice corrosion.

Data Indicate that the corrosivity

of the geothermal fiuld corrodibility.

Data indicate that the corrosivity of the geothermal fiuid has increased and the metal corrodibility has decreased.

The data indicate that the corrosivity of the geothermal fluid has decreased as has the metal corrodiblitty. Most of the corrosion was localized as pitting and crevice corrosion. In some cases the pitting was of the same order of magnitude as the surface roughness of the coupons and is indicated by "Slight".

The data indicate that the corros-

iveness of the geothermal fluid has

decreased as has the metal corrodibility. 
TABLE VIII (Contd)

\begin{tabular}{|c|c|c|c|c|c|c|c|}
\hline Alloy & $\begin{array}{l}\text { Loss } \\
\text { Units* }\end{array}$ & $\mathbf{A}_{\mathbf{1}}$ & B & $A_{2}$ & $A_{t}$ & $A_{t+1}$ & Remarks \\
\hline $\begin{array}{l}\text { Low-Carbon Stee1 } \\
\text { (ASTM A 515) }\end{array}$ & $\operatorname{mdd}$ & $75.2 \times 10^{-2}$ & $8.6 \times 10^{-2}$ & $\begin{array}{l}0 \\
0\end{array}$ & $\frac{9.5}{4.8} \times 10^{-2}$ & $\begin{array}{l}9.5 \\
4.8\end{array} \times 10^{-2}$ & \multirow{2}{*}{$\begin{array}{l}\text { Data indicate that the corrosivity } \\
\text { of the geothermal fluid has increased } \\
\text { and the metal corrodibility has } \\
\text { decreased. }\end{array}$} \\
\hline $\begin{array}{l}\text { Crevice Corrosion } \\
\text { Pitting }\end{array}$ & $m$ & $\overline{0.076}$ & 0.03 & $-\cdots$ & $\begin{array}{l}0.18 \\
0.076\end{array}$ & $\begin{array}{l}0.02 \\
---\end{array}$ & \\
\hline $9 \%$ Cr Steel & $\mathrm{mdd}$. & $1.8 \times 10^{-2}$ & $\frac{2.7}{1.4} \times 10^{-2}$ & $7^{-1.4} \times 10^{-3}$ & $1.7 \times 10^{-2}$ & $2.0 \times 10^{-2}$ & \multirow[t]{2}{*}{$\begin{array}{l}\text { Data indicate that the corrosivity } \\
\text { of the geothermal fluid has decreased } \\
\text { as has the metal corrodibility. }\end{array}$} \\
\hline $\begin{array}{l}\text { Crevice Corrosion } \\
\text { Pitting }\end{array}$ & $m_{m}$ & $\overline{0.04}$ & $\cdots$ & --- & 0.033 & $\overline{0.1}$ & \\
\hline $\begin{array}{l}\text { Cor-Ten (High-strength) } \\
\text { low alloy steel) }\end{array}$ & $\begin{array}{l}m d d \\
m m / A\end{array}$ & $8.7 \times 10^{-2}$ & $3.0 \times 10^{-2}$ & $2.5 \times 10^{-3}$ & $2.8 \times 10^{-2}$ & $\frac{5.3}{2.7} \times 10^{-2}$ & \multirow{2}{*}{$\begin{array}{l}\text { Data indicate that the corros fiveness } \\
\text { of the geothermal fluid has decreased } \\
\text { as has metal corrodibility. }\end{array}$} \\
\hline $\begin{array}{l}\text { Crevice Corrosion } \\
\text { Pitting }\end{array}$ & $\operatorname{mim}_{\min }$ & 0.013 & $\begin{array}{l}0.025 \\
0.04\end{array}$ & $\overline{--}$ & $\overline{0.04}$ & $\begin{array}{l}0.1 \\
0.05\end{array}$ & \\
\hline $\begin{array}{l}\text { ASTM A } 48 \\
\text { (Gray cast iron) }\end{array}$ & $\begin{array}{l}\operatorname{mdd} \\
\mathrm{mm} / \mathrm{A}\end{array}$ & $5.7^{11.4} \times 10^{-2}$ & $8.8 \times 10^{-2}$ & $1.0 \times 10^{-2}$ & $8.4 \times 10^{-2}$ & $8.2 \times 10^{-2}$ & \multirow{2}{*}{$\begin{array}{l}\text { Data indicate that the corrosiveness } \\
\text { of the geothermal fiuid has decreased } \\
\text { with time, as has metal corrodibility. }\end{array}$} \\
\hline $\begin{array}{l}\text { Crevice Corrosion } \\
\text { Pftting }\end{array}$ & $\operatorname{mim}$ & $\ddot{\cdots}$ & $\begin{array}{l}0.04 \\
0.04\end{array}$ & $-\cdots$ & $\begin{array}{l}0.05 \\
0.03\end{array}$ & $\begin{array}{l}0.10 \\
0.06\end{array}$ & \\
\hline $\begin{array}{l}\text { AISI } 4140 \text { (Low alloy } \\
\text { steel) }\end{array}$ & $\frac{\mathrm{mdd}}{\mathrm{mm} / \mathrm{A}}$ & $\begin{array}{l}7.5 \\
3.8\end{array} \times 10^{-2}$ & $\begin{array}{l}6.0 \\
3.0\end{array} \times 10^{-2}$ & $8.0 \times 10^{-3}$ & $2.5 \times 10^{-2}$ & $\begin{array}{l}4.1 \\
2.1 \times 10^{-2}\end{array}$ & \multirow{2}{*}{$\begin{array}{l}\text { Data indicate that corrosivity of } \\
\text { the geothermal fluid has decreased } \\
\text { with time as has the metal corrodi- } \\
\text { bility. }\end{array}$} \\
\hline $\begin{array}{l}\text { Crevice Corrosion } \\
\text { Pitting }\end{array}$ & $\operatorname{mim}$ & $\begin{array}{l}0.02 \\
0.02\end{array}$ & $\begin{array}{l}0.08 \\
0.25\end{array}$ & $-\cdots$ & $\begin{array}{l}0.08 \\
0.04\end{array}$ & $\begin{array}{l}0.08 \\
0.1\end{array}$ & \\
\hline AISI 410 Staínless Steel & $\begin{array}{l}\text { mdd } \\
m m / A\end{array}$ & $\begin{array}{l}1.0 \\
4.7 \times 10^{-3}\end{array}$ & $4.7 \times 10^{-3}$ & $1.0 \times 10^{-3}$ & $\begin{array}{l}1.0 \\
4.7 \times 10^{-3}\end{array}$ & $5.7 \times 10^{-3}$ & \multirow{2}{*}{$\begin{array}{l}\text { Data indicate that corrosivity of } \\
\text { the geothermal flufd has decreased } \\
\text { with time as has the metal corrodi- } \\
\text { bility. This is a very corrosion- } \\
\text { resistant alloy; most of the cor- } \\
\text { rosion damage was localized and due } \\
\text { to pitting and crevice corrosion. }\end{array}$} \\
\hline $\begin{array}{l}\text { Crevice Corrosion } \\
\text { Pitting }\end{array}$ & $\mathrm{mm}$ & $\begin{array}{l}0.2 \\
0.025\end{array}$ & 0.05 & --- & $\begin{array}{l}0.22 \\
0.05\end{array}$ & $\begin{array}{l}0.18 \\
0.30\end{array}$ & \\
\hline AISI 440 Stainless Steel & $\begin{array}{l}\mathrm{mdd} \\
\mathrm{mm} / \mathrm{A}\end{array}$ & $6.6 \times 10^{-3}$ & $6.1 \times 10^{-3}$ & $\frac{-0.7}{2.9} \times 10^{-3}$ & $2.2 \times 10^{-2}$ & $7.5 \times 10^{-3}$ & \multirow{3}{*}{$\begin{array}{l}\text { Data Indicate that corrosivity of } \\
\text { the geothermal fluid has decreased } \\
\text { with time as has the metal corrodi- } \\
\text { bility. This is a very corrosion- } \\
\text { resistant alloy and most of the } \\
\text { corrosion damage was localized and } \\
\text { due to pitting and crevice corrosion. }\end{array}$} \\
\hline $\begin{array}{l}\text { Crevice Corrosion } \\
\text { Pitting }\end{array}$ & $\mathrm{mm}_{\mathrm{m}}$ & $\begin{array}{l}0.23 \\
0.23\end{array}$ & $\begin{array}{l}0.03 \\
0.03\end{array}$ & --- & $\begin{array}{l}0.51 \\
0.41\end{array}$ & $\begin{array}{l}0.25 \\
0.05\end{array}$ & \\
\hline $\begin{array}{l}\text { *mdd: Average corrosion } \\
\mathrm{mm} / \mathrm{A}: \text { Average corrosion } \\
\mathrm{mm}: \text { Penetration }\end{array}$ & $\begin{array}{l}\text { in } \mathrm{mg} \cdot \mathrm{dn} \\
\text { in } \mathrm{mm} / \mathrm{c}\end{array}$ & day $^{-1}$ & & & & & \\
\hline
\end{tabular}


The AISI 316 stainless steel showed some localized corrosion and Class 3 designation seems more appropriate than Class 2 for this material. The aluminum bronze casting alloy, AMPCO 12, belongs in Class 3 as determined by weight loss and by observations of localized corrosion.

The aluminum bronze with 4 to $5 \%$ nickel (AMPCO 483) had a corrosion rate up to four times that of otherwise similar but nickel-free materials. Pitting and dealloying precluded a higher classification than No. 4. Pitting and crevice corrosion in AISI 304 stainless steel is severe enough to put it in class 4 but not so severe that it could not be used in special applications with prior testing and evaluation. The plain carbon steels, gray cast iron, and the alloy steels suffered from general and localized corrosion and are in Class 4.

The martensitic stainless steels, AISI 410 and 440 , are frequently used as pump shafting. Because of severe crevice corrosion and pitting during testing these materials were placed in Class 5 . The use of these materials in applications where crevices can develop should be preceded by carefur testing and analysis.

Pitting and crevice corrosion were evident in many samples in the weight-loss tests. Because the extent of these forms of localized corrosion attack was more amenable to measurement subsequent to cleaning, the samples were cleaned and weighed before measuring pit depth.

The materials in acceptability Classes 1 and 2 were generally free of pits and evidence of crevice corrosion. The principal exception was Hastelloy $G$ which showed one rather prominent pit near the edge of the TFE washer.

The AISI 410 and 440 stainless steels were badly pitted in the area of the beveled edge of the TFE washer as well as in nonoccluded regions. The weight loss in these alloys is due, primarily, to pitting and crevice corrosion. Similar results were obtained for AISI 304 stainless steel, though the pits were not as numerous or deep as for the 400-series alloys. AISI 316 stainless steel was also pitted but to a lesser extent than the 304 coupons, and would be acceptable in many applications. 
The low alloy steels were pitted and exhibited crevice corrosion. The plain carbon steels and gray cast iron were pitted worse than the low alloy steels.

Of the materials examined, the AISI 410 and 440 stainless steels showed the most catastrophic attack. These results lead to the conclusion that these, and similar, alloys should not be used in the hot geothermal fluid under conditions where crevices can be generated. Such applications include pump shafts where seals and bearings could provide the mechanical condition necessary for promotion of crevice corrosion. The alloys noted here are martensitic, ie, they have a two-phase structure. Precipitation-hardening stainless steels such as 17-4PH are modifications of the austenitic stainless steels. In these alloys the nickel content is lower and alloy additions of elements such as aluminum, copper, molybdenum and niobium are made to generate the second phase that results in hardening. These materials are similar to AISI 304 stainless steel in regard to corrosion resistance in most environments [43]. Because the 17-4PH material is used in valve stem applications, its use in the Raft River geothermal fluid should be preceded by careful testing and evaluation.

As shown in Table VIII, weight change $B$ is greater than weight change $A_{2}$ for all cases. From this observation the conclusion was reached that the corrodibility of the metal decreased with time. The explanation for this is the growth of corrosion product scales or the deposition of minerals from the geothermal fluids. These scales would have the effect of limiting access of the geothermal fluid to the surface of the metal, thereby decreasing general attack. One adverse effect of these scales is their tendency to support localized corrosion, for example, pitting or so-called "under-film" corrosion.

Changes in the corrosiveness of the geothermal fluids are less easy to analyze than the metal corrodibility data[a]. If the data for the less-corrosion-resistant metals are selected for analysis (they show weight losses somewhat greater than the sensitivity of the measurements), the general trend is in the direction of the geothermal fluid becoming 
less aggressive. The data for the highly resistant alloys are in the range of the limit of sensitivity of the tests and are disregarded in the present analysis.

If the geothermal fluid is becoming less aggressive as the formation is produced, this change will have some long-term significance. However, the data are sufficiently well separated that selection of materials of construction in the near term is made reasonably easy.

\section{TUBE-TO-TUBESHEET TEST}

The primary objective of this test was to identify the magnitudes of crevice and galvanic corrosion processes in the joint region of tubes rolled into tubesheets.

\subsection{Test Location}

The sample assembly for the tube-to-tubesheet test was contained in the section following the pressure, temperature and flow transducers in the upper flow line of the materials test section on the Mobile Components-Test Trailer.

\subsection{Environment}

The geothermal fluid used in this test was from RRGE 1 . Its composition is described in Table I. The nominal temperature of the fluid was $130^{\circ} \mathrm{C}\left(265^{\circ} \mathrm{F}\right)$.

Flow around the test assembly was thought to be small compared to flow through the tubes of the simulated heat exchanger. Flow was adjusted to about $1.5 \mathrm{~m} / \mathrm{s}(5 \mathrm{ft} / \mathrm{sec})$ through the tubes.

\subsection{Materials}

This test was designed to evaluate crevice and galvanic corrosion in a tube-to-tubesheet configuration where the tube is rolled into the 
tubesheet. For the tube materials available for boiler and preheater construction, the candidate tubesheet materials are naval brass, aluminum bronze or low-carbon steel. Typical analyses for these alloys are given in Tables A-III and A-IV.

Tube material selection was based largely on the results of the screening and short-term evaluation tests. The materials used in the actual tests are indicated in Table IX along with the tubesheet material for each combination.

\section{TABLE IX}

MATERIALS FOR THE TUBE-TO-TUBESHEET CORROSION TEST

Tube Material

Low-Carbon Steel

304 SS

316 SS

Al legheny-Ludlum $6 \mathrm{X}$

Admiralty Brass (As)

70Cu/30Ni

Hastelloy $\mathrm{G}$
Tubesheet Material

Low-Carbon Steel Naval Brass
Yes No

Yes No

Yes No

Yes No

No Yes

Yes Yes

Yes No

Admiralty brass has a higher copper content than Muntz metal or naval brass (see Table A-III for the nominal composition of these alloys). Because of the tendency toward lower corrosion rates for copper alloys of higher copper content and particularly when small alloy additions of tin are made ${ }^{[33]}$, admiralty brass was selected for testing in the tube-to-tubesheet test. Naval brass, because of availability, was used to simulate the typical copper-base alloy tubesheet materials.

Low-carbon steel tubes (ASTM A 179) were used to simulate response of these materials to the environment. The flat low-carbon steel coupons did not give the hard, black magnetite films expected of this material. These results suggested that differences in fabrication of rolled and drawn materials may have an effect on the corrosion films formed; this is another reason for testing low-carbon steel tubing. 
Allegheny-Ludl um $6 \mathrm{X}$ and Hastelloy $\mathrm{G}$. were tested to provide data on materials thought to be highly resistant to corrosion by Raft River geothermal fluids.

The AISI 304 and 316 stainless steels represent materials that are in the upper range of cost-effective materials in the present economic. situation.

The 70Cu/30Ni alloy was tested to give some additional data on this commonly used heat exchanger material.

\subsection{Test Assembly}

The purpose of the test was to evaluate galvanic and crevice corrosion in the joint between the tube and the tubesheet. In order to simulate the typical tube-to-tubesheet configuration, tubes of various materials were rolled into small tubesheet simulators as shown in Figure 13. The rolling process was identical to that used in commercial heat exchangers. The tube/tubesheet assemblies were mounted in TFE fixtures bolted to a $15.9-\mathrm{mm}(0.625-\mathrm{in}$.) diameter AISI 304 stainless steel rod. Each TFE fixture would hold five of the tube/tubesheet assemblies. Once the fixture was assembled, it was inserted in the flow chamber. Geothermal fluid was allowed to enter the "shell side" of the assembly; flow through this plenum was negligible compared with flow through the tubes. A photograph of the completed assembly is shown in Figure 14 .

Subsequent to the completion of the test an analysis of the experimental techniques suggested that the simulated tubesheet may have been stressed beyond the elastic limit of the material during the tube rolling operation. Further tests are planned to evaluate this possibility. However, if some plastic deformation of the tubesheet did occur, the joint would not be as tight as would normally be obtained and thus a greater tendency for crevice corrosion would exist. In this respect then, the present test results would be conservative. 


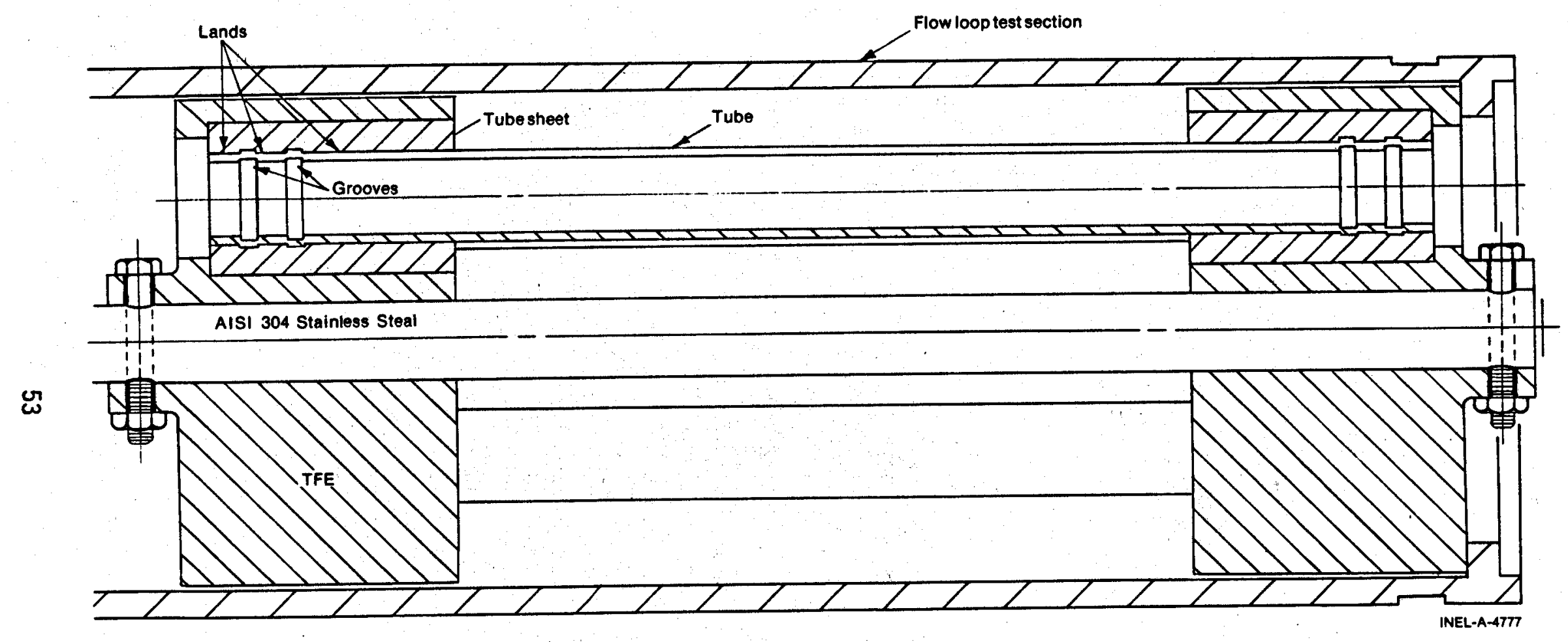

Fig. 13. Tube, tubesheet and TFE holders. 


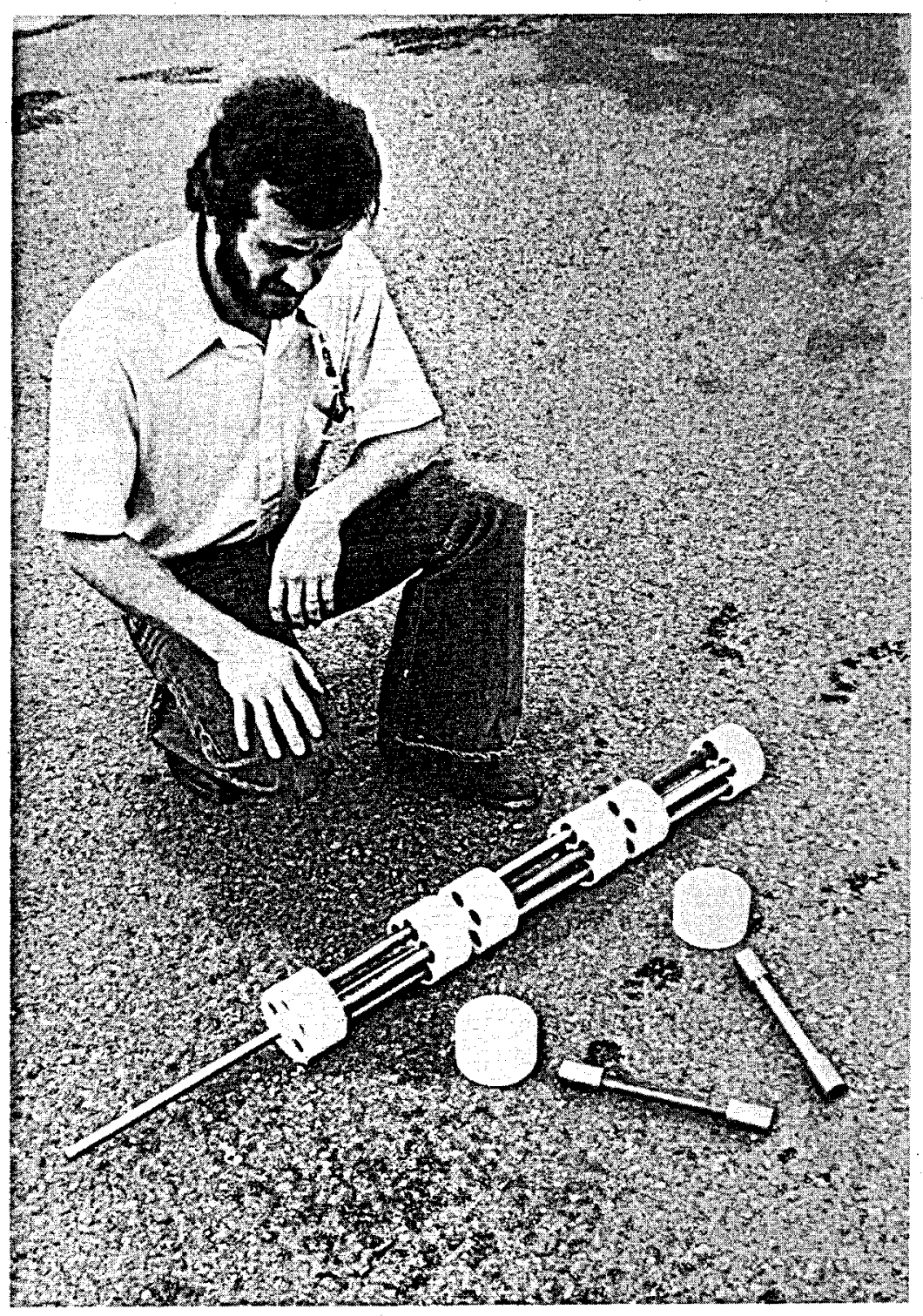

Fig. 14. Tube-to-tubesheet test assembly. 


\subsection{Schedule}

The urgent need for materials test data relatable to the potential combination of tube and tubesheet materials in the boilers and preheaters of the Thermal Loop Facility precluded a long test. All of the samples were emplaced on February 16, 1977. Half of the samples were removed two weeks later, on March 1, 1977, and the test on the remaining samples was terminated on March 22, 1977.

\subsection{Results}

In general, no severe degradation due to galvanic and/or crevice corrosion was noted in the materials likely to be selected for use in Thermal Loop Facility heat exchangers. Some pitting was identified in the $70 \mathrm{Cu} / 30 \mathrm{Ni}$ tubing but this material is no longer considered a viable candidate for usage in the boiler/preheater system due to excessive corrosion induced by the hydrogen sulfide in the geothermal fluid.

The test assembly, as described in Section 3.4, consisted of a simulated tubesheet at each end of a 25.4-cm (10-in.) long tube. The tubes were $19 \mathrm{~mm}(0.75 \mathrm{in.})$ OD with wall thickness varying according to material availability. The tubesheets were either low-carbon steel or naval brass. The low-carbon steel was used with the iron and nickel alloy tubes; the naval brass was used with the copper alloy tubes.

3.6.1 Tubesheet Materials. Specific tubesheet material behavior is described in detail in the following paragraphs.

Low-Carbon Steel Tubesheets. In every case, the low-carbon steel tubesheets had an adherent black tarnish on the outside surface. Cor= rosion behavior of the inner surfaces, those adjacent to the tubes, varied according to location and was remarkedly similar in all cases, both with respect to kinds and amounts of corrosion products and in its extent from the entrance end and the discharge end of the tube. Circumferential variations in corrosion were small. 
In general, the land from the entrance end to the first groove was coated with a film of black tarnish. Occasionally, a small amount of yellow or rust-red corrosion product would be found on this land. The presence of the black tarnish suggests that geothermal fluid diffused into this zone in sufficient amounts to cause the observed tarnish as well as other corrosion products. No pitting was detected on this land.

No black tarnish was noted in the grooves of the tubesheet but in every case both grooves contained a thin layer of yellow and/or rust-red corrosion products. These corrosion products were easily removed with light scraping. The rust-red scale was frequently present as a continuous scale; otherwise it appeared to form microtubercles. A pit should be found associated with these microtubercles; however, any pits which may have been present were too small to resolve at magnifications up to 70 diameters. The two grooves were similar, differing only in relative amounts of corrosion or corrosion products.

The land between the grooves generally had spots of yellow or rustred corrosion products. The spots did not, generally, run together to cover a significant portion of the land. The amount of scale on the land was usually less than that in either of the grooves. The rust-red spots were, typically, microtubercles. No pits were seen on the land.

The last $32 \mathrm{~mm}(1.25 \mathrm{in}$.$) of the tubesheet had two kinds of cor-$ rosion product. The last 3 to $13 \mathrm{~mm}(0.12$ to $0.5 \mathrm{in.})$ portion was generally coated with black tarnish. The remainder of the land was spotted with yellow and/or rust-red scale. The rust-red corrosion product was more prevalent than the yellow material. There was slight intermixing of the rust-red scale with the black tarnish. In some instances the thickness of the rust-red scale was great enough to bridge the distance between the tubesheet and the tube. No pitting was seen in the land.

Naval Brass Tubesheets. The simulated tube sheets had a variable light purple tarnish on the exterior surfaces, but there was no evidence of pitting on these surfaces. The interior surfaces of the tube sheets 
showed some purple corrosion film extending about 0.25 to $2.5 \mathrm{~mm}(0.01$ to 0.1 in.) from each end of the tubesheet. Very slight dealloying appears to have taken place in the grooves, otherwise the interior surfaces are nearly free of visible corrosion.

The naval brass tubesheets appear to be substantially more resistant to attack by the geothermal fluid than the low-carbon steel material.

3.6.2 Simulated Heat Exchanger Tubes. Where the tube exteriors were protected by the tubesheet they were remarkedly similar in appearance from one tube to another and nearly free of corrosion. Considerable differences were observed, however, on the ID of the tubes in this test. The test was designed to study galvanic and crevice corrosion between the tubesheets and the tubes rather than to study corrosion on the interior of the tubes. Tubing materials are listed in Table IX.

The tube expansion process induces high levels of residual stress from cold work, particularly where the tubes are expanded into the grooves. Differences in corrosion resistance were observed between the cold-worked and the unworked areas.

Except for the $70 \mathrm{Cu} / 30 \mathrm{Ni}$ alloy, no extensive pitting was observed on the $O D$ of the tubing. The individual materials are discussed in more detail below. While differences were observed between tube materials in this experiment and flat corrosion coupons used in the short-term evaluation test, the duration of the present test was too short ( 2 or 5 weeks) to make accurate judgments regarding the acceptability of the tube materials for Raft River geothermal fluid service.

Low-Carbon Steel. The exterior surface exposed to the geothermal fluid was tarnished deep black. No pitting was seen on this surface. The portion of the tube inside the tubesheet showed black tarnish back to the first groove and inward from the shell side of the tubesheet about $3 \mathrm{~mm}(0.13 \mathrm{in.})$. Spots of rust-red scale were observed but these 
were neither extensive nor tightly adherent. Their origin may have been the tubesheet.

The cold-worked surfaces on the interior of the tube showed small halos that had small pits near their centers. The pits were very shallow and the halos frequently extended in the flow direction.

The surface roughness of the tube that was not rolled into the tubesheet was significantly greater than the rolled section. The tooling mark, and other artifacts, appeared to have been accentuated by exposure to the fluid, but no extensive corrosion was observed.

AISI 304 Stainless Steel. The exterior surface of the tubing exposed to the geothermal fluid was essentially free of corrosion. The portion of the tube inserted into the tubesheet showed black tarnish back to the first groove and for about 7.5 to $10 \mathrm{~mm}(0.3$ to $0.39 \mathrm{in}$.) from the end of the shell side of the tubesheet. The tarnish probably came from the tubesheet. No pitting was seen on the exterior of the tube under the tubesheet.

The cold-worked interior surface showed scattered pitting under red-to-brown microtubercles. Pitting was not readily apparent in the tubing that had been rolled into the tubesheet.

These observations of AISI 304 stainless steel tubing indicated that the corrosion is less extensive than on the flat coupons of the same material used in the short-term evaluation test. Further testing may be required to clarify the nature of the differences.

AISI 316 Stainless Steel. The outside surfaces exposed to the geothermal fluid were visually free of corrosion. The section of the tubing within the tubesheet showed black tarnish back to the first groove and for about $13 \mathrm{~mm}(0.5 \mathrm{in}$.) from the shell side of the tubesheet. There were some pit-like areas that probably resulted from mechanical damage during expansion of the tube into the tubesheet; the pits do not appear to be corrosion-related. 
The interior surface showed numerous pits surrounded by halos of corrosion products and covered by microtubercles. In other cases the pits appeared to be caused by mechanical damage. Pitting was present in both the cold-worked and nonworked areas.

Hastelloy $G$. The exterior surface of the tube exposed to the geothermal fluid was free of visual indications of corrosion. The portion covered by the tubesheet was covered with black tarnish. At the time the tube was rolled into the tubesheet the vendor indicated that the tube was difficult to expand. The toughness of the tube probably precluded a good seal between the tube and the tubesheet, resulting in more extensive tarnish than in other tube and tubesheet combinations.

The interior surfaces of the tubes showed pitting associated with halos of material that appeared to be corrosion products. These were more prevalent in the rolled section of the tube than in the nonworked section. Other pits were free from halos and appeared to be mechanical damage. Some deep pits were found in the weld zone; these appeared to be defects caused by improper welding.

Allegheny-Ludlum $6 \mathrm{X}$. The exterior surface of each tube exposed to the geothermal fluid was free of visual indications of corrosion. The portion of the tube rolled into the tubesheet showed black tarnish extending back to the first groove and for about $20 \mathrm{~mm}(0.75 \mathrm{in}$.) from the shell-side end of the tubesheet. Some yellow and rust-red corrosion products were present but did not show visual evidence of underlying corrosion. These products are thought to come from the low-carbon steel tubesheet.

The interior surface of the tube showed some deep pits associated with the weld but did not have other characteristics associated with corrosion. These defects are thought to have resulted from improper welding techniques. Some halos, similar to those associated with corrosion pits in other materials, were seen. However, if pits or other corrosion were present, they were of the same magnitude as the surface roughness of the tubing. 
Admiralty Brass (Arsenic Stabilized). The exterior surface of the tube exposed to the geothermal fluid was covered with a thin film of purple-colored corrosion products. At points where the tube was mechanically damaged (scratches, etc) the scale was somewhat thicker. There was very little attack in the portion covered by the tubesheet.

The internal surface of the tube was covered with a deep purpleblack scale. The cold-worked area appeared to be more severely attacked than the annealed portion of the tube. From observations on flat copper-alloy coupons, the scales are probably sulfides and provide some measure of corrosion protection to the substrate metal.

Tests in progress will provide better definition of the corrosion rate of admiralty brass than is available from the present test data. These tests incorporate both flat and tubing coupons of admiralty brass, in close proximity to one another.

From qualitative results of the present test, admiralty brass appears to be an acceptable material for heat exchanger applications.

CA 715 70Copper/30Nickel. The exterior surface of the tubing exposed to the geothermal fluid was covered with a thick purple-to-black scale similar to scales seen on flat coupons in the screening test (see Section III, 1.6). The tubing showed extensive grooving and pitting, as much as $0.03 \mathrm{~mm}$ ( $0.0012 \mathrm{in.})$ deep. There was relatively little corrosion on the portion of the exterior surface that was protected by the tubesheet.

These observations on 70Cu/30Ni tubing confirm the results of coupon weight losses and observations of similar alloy material in the screening test.

3.6.3 Scales Not Associated With Corrosion. In a few instances a clear colorless-to-translucent-white crystalline material was found in the crevice between the tubesheet and tube at the shell side end of the tubesheet. The appearance of the scale suggested calcite. Scrapings of 
the scale effervesced in dilute hydrochloric acid, confirming that the scales were carbonates.

These results suggest that the geothermal fluid is unstable with respect to calcite deposition. However, the scales were not found in nonoccluded areas on any sample. The reason for calcite deposition in occluded regions but not elsewhere is not readily evident.

\section{SHELL-AND-TUBE HEAT EXCHANGER FOULING TESTS: \\ POSTTEST EXAMINATION FOR CORROSION}

The fouling test was conducted to evaluate the probable fouling factors for selected tube materials in a shell-and-tube heat exchanger. After the fouling exposure the tube and tubesheets were sectioned and the parts visually examined for corrosion and corrosion-related phenomena.

\subsection{Test Location}

The heat exchanger fouling test was conducted in the four shelland-tube heat exchangers on the Mobile Components-Test Trailer, shown in Figure 11. These heat exchangers were designed and instrumented to provide fouling data on a number of materials at one time. They may be operated in series or in parallel, as defined by the needs of a particular experiment.

\subsection{Environment}

The geothermal fluid used in this test was from RRGE 1 . Its analysis is given in Table I of this report. The temperature varied from one end of the tube to the other due to heat transfer. The nominal temperature at each end of the tube is reported in the sections dealing with the individual tubes.

Flow through the tubes was regulated to about $1.5 \mathrm{~m} / \mathrm{s}(5 \mathrm{ft} / \mathrm{sec})$ velocity. 


\subsection{Materials}

Materials selected for these tests fell in the following categories:

1. The tube materials were expected to be essentially immune to corrosion. Thus all of the fouling would be the result of deposition from the water. Titanium, AISI 304 stainless steel, and Hastelloy $G$ were the tube materials in this category.

2. The tube materials were expected to both foul and corrode, giving indications of the contribution of corrosion to the observed fouling tendency. Low-carbon steel and Monel 400 were the tube materials in this category.

3. The tube materials are commonly used for boiler and preheater heat exchanger applications. Hastelloy $G$ and arsenic-stabilized admiralty brass were the materials in this category.

In most cases the tube and tubesheet materials were of the same alloy. The exception was the admiralty brass tube, in which case a naval brass tubesheet was used.

The low-carbon steel, AISI 316 stainless steel, Allegheny-Ludlum 6X and admiralty brass tubes are still under test at the time of this writing and are not discussed in this report.

\subsection{Test Assembly}

Design and fabrication of components for the she11-and-tube fouling experiment were done along conventional lines, that is, the tubes were rolled into the tubesheet and the floating head. A diagram of the assembly is shown in Figure 15. Leakage between the shell side and the tube side required retrofit seal welding of the tubes into both the tubesheet and the floating head. In the case of the admiralty brass tube and naval brass tubesheet, silver soldering was used, rather than welding, to avoid loss of zinc from the materials. 




Fig. 15. Tube assembly for heat exchanger foul ing tests. 


\subsection{Schedule}

The examination of the tubes from these tests for corrosion or corrosion-related deterioration is done after completion of the fouling experiments. Table $X$ indicates the tubes that have been examined visually for corrosion.

TABLE $X$

EXPOSURE SCHEDULE FOR TUBES IN THE SHELL-AND-TUBE HEAT EXCHANGER FOULING TEST

$\begin{array}{lll}\text { Tube Material } & \frac{\text { Date In }}{304 \text { SS }} & \frac{\text { Date Out }}{1 / 11 / 77} \\ \text { Titanium } & 9 / 15 / 76 & \\ \text { Mone1 } 400 & 9 / 15 / 76 & 1 / 11 / 77 \\ \text { Low-carbon steel } & 1 / 11 / 77 & 4 / 13 / 77 \\ 316 \text { SS } & 1 / 11 / 77 & \text { In Test } \\ \text { Admiralty brass } & 2 / 24 / 77 & \text { In Test } \\ \text { (arsenic-stabilized) } & 4 / 13 / 77 & \text { In Test }\end{array}$

\subsection{Results}

The heat exchanger fouling tests were reported by Mines and Whitbeck ${ }^{\text {[44] }}$. The purpose of these tests was to determine fouling rates and magnitudes as functions of material, heat flux and fluid properties. The test results were used to assist in the selection of materials for the boiler and preheater heat exchangers for the Thermal Loop Facility and are critical in sizing the heat transfer area of the units.

As follow-on, the tubesheet and floating head ends were sectioned from each heat exchanger tube assembly for visual examination. In addition to the tubing which was rolled and seal-welded into these end pieces, an additional $50-75 \mathrm{~mm}$ (2-3 in.) of tubing was taken next to the tubesheet and floating head for examination. The tubesheets, floating ends, and tubes were examined for evidence of pitting and general corrosion. 
Titanium, Monel 400 and AISI 304 stainless steel tube assemblies were available for examination at the time of writing. Carbon steel and admiralty brass tube assemblies are in various stages of fouling testing and will be examined at a later date. The results of the present examinations are given below.

4.6.1 Titanium Tube Assembly. Fluid temperatures and the test behavior of structural components of this assembly are noted below.

Tubesheet. The temperature at the tubesheet end of the tube was $56-71^{\circ} \mathrm{C}\left(183-205^{\circ} \mathrm{F}\right)$. No attack from the geothermal fluid was observed on this portion of the assembly.

Floating End. The temperature range at this end of the tube was $84-96^{\circ} \mathrm{C}\left(183-205^{\circ} \mathrm{F}\right)$. No attack from the geothermal fluid was observed on this portion of the assembly.

Tubing. This was welded tubing. No attack that could be attributed to geothermal fluid was observed.

\subsubsection{AISI 304 Stainless Steel Tube Assembly. Fluid temp-} eratures and the test behavior of structural components of this assembly are noted below.

Tubesheet. The temperature range at this end of the tube was 128$135^{\circ} \mathrm{C}\left(263-275^{\circ} \mathrm{F}\right)$. No attack from the geothermal fluid was observed on this part of the assembly.

Floating End. The temperature range of this part of the assembly was $54-96^{\circ} \mathrm{C}\left(130-205^{\circ} \mathrm{F}\right)$. No attack from the geothermal fluid was observed on this portion of the assembly.

Tubing. A few very shallow pits were observed in the tubesheet area. No corrosion was observed near the floating head. The tubing was not examined for evidence of stress corrosion cracking. 
4.6.3 Monel 400 Tube Assembly. Fluid temperatures and the test behavior of structural components of this assembly are noted below.

Tubesheet. The temperature range of this end of the assembly was $127-135^{\circ} \mathrm{C}\left(260-275^{\circ} \mathrm{F}\right)$. A purple-to-black scale was observed on the portion of the tube exposed to the hot geothermal fluid. The seal weld had three deep pits that appeared to be artifacts from poor welding rather than from corrosion attack.

Floating End. The temperature range of this end of the assembly was $66-82^{\circ} \mathrm{C}\left(150-180^{\circ} \mathrm{F}\right)$. A black scale was found on this portion of the floating end exposed to the hot geothermal fluid. The seal weld had two deep pits that appeared to be artifacts from poor welding rather than from corrosion attack.

Tubing. A thin scale which varied in color from purplish-black at the hot end of the tube to a deeper black at the cold end of the tube was observed. This scale was easily removed by light scraping. A very thin, transparent, yellowish scale occurs between the black deposit and the base metal; this scale is present at the cold end and absent at the hot end. Some slight pitting was observed on the inside surface of the tubing.

\subsection{Conclusion}

The tubing corrosion tests indicate a definite change in corrosion rate and appearance from the flat coupon tests. Except for the titanium, the tubing was seamless and presumably was drawn, the flat coupons were from rolled sheets. The temperatures of the heat exchanger tubes were somewhat lower than those of the flat coupons. Until further test data are available the main conclusion drawn from this post-fouling-test examination is that the lower temperature contributes significantly to the lower corrosion rate observed in the above materials. Additional tests are in progress to better define the parameters affecting corrosion of the above materials. 


\section{OVERALL CONCLUSIONS AND RECOMMENDATIONS}

The results of the foregoing tests have been definitive with respect to some alloys and nebulous for others. In some instances reliance has been placed on the recommendations of experts in the selection of materials. The following conclusions and recommendations are grouped according to generic classes of alloys.

Aluminum Alloys. The results of the screening tests were definitive with respect to the 1100,5052 , and 6061 aluminum alloys. These materials are unacceptable for use in contact with the hot geothermal fluid.

Aluminum and its alloys depend on the stability of adherent oxide films for corrosion resistance. Raft River geothermal fluid is reducing, Eh $=+105 \mathrm{mV}$. While this potential is too small to result in reduction of the oxide it may be large enough, at the temperature and $\mathrm{pH}$ of the hot fluid, to retard or prevent repair of damaged oxide sites. In any event, the corrosion rate is much too large for further consideration of these materials in the hot geothermal fluid.

Brasses and Bronzes. These materials gave acceptably low corrosion rates in the hot geothermal fluid. There appears to be a decreasing tendency toward dealloying with increasing copper content. Further tests are in progress to more accurately define the relation of the copper content of the base metal to the corrosion rate in the hot geothermal fluid.

Based on the results of our tests, and on expert opinion, admiralty brass has been selected as tube material for the boiler and preheaters. Aluminum bronze has been selected as tubesheet material because of its good weldability and low corrosion rate.

The most unfavorable data from the brass and bronze tests concern aluminum bronze containing 4-5\% nicke1. This material corroded at a rate about four times that of a similar, but nickel-free, material. The 
observed corrosion rate of the aluminum-nickel bronze was unacceptable and this alloy cannot be recommended for service in hot geothermal fluid environments. The reason for the accelerated rate of corrosion on this material appears to be a relatively selective attack on the nickel by sulfides in the geothermal fluid.

Copper-Nickel Alloys. This group includes Monel 400,70Cu/30Ni, and $90 \mathrm{Cu} / 10 \mathrm{Ni}$ alloys. As a group these alloys perform very well in seawater applications. In the geothermal fluid from RRGE 1, however, their performance was very poor. Large areas of corrosion were observed, surrounded by "mesas" of less corroded metal.

The corrosion behavior of these alloys has precluded their use in hot geothermal fluids containing even small amounts of sulfides. A further test of the 70Cu/30Ni alloy is in progress to ascertain if significant corrosion behavior differences exist between the flat coupons and samples of tubing.

Plain Carbon Steels. Pitting, crevice, and general corrosion in the plain carbon steels was too great for these materials to be viable candidates for thin structural members in direct contact with hot geothermal fluids. The gray cast iron showed some pitting and crevice corrosion but very little general corrosion.

Plain carbon steel and gray cast iron can be recommended for hot geothermal fluids service in thick structural members such as valves, fittings and pump parts if care is taken to monitor their condition.

Low-Alloy Steels. Pitting and crevice corrosion in these materials was sufficiently severe to preclude their use in some applications where they are frequently specified. These materials will be tested in a cooling tower environment to determine their applicability in aerated, cooled, and concentrated geothermal fluid.

Martensitic Stainless Steels. AISI 410 and AISI 4.40A stainless steels were the only two grades of martensitic stainless steels tested. 
The depth of corrosion was as much as $0.22 \mathrm{~mm}(0.008 \mathrm{in}$.$) in$ 109 days. The typical use of these alloys is in pump shafts where crevices in bearings and seals are characteristic. Because of the severe corrosion in the test coupons, the use of these, or similar, alloys in any application involving hot geothermal fluid is not recommended.

Austenitic Stainless Steels. Several grades of austenitic stainless steel have been tested. These are AISI types 304 and 316 and the Allegheny-Ludlum alloys $6 \mathrm{X}$ and 216 . The stability of these materials in the geothermal fluid varies according to the chromium, nickel and molybdenum content of the steel. The molybdenum-containing steels were somewhat more resistant to corrosion than was AISI 304 stainless steel.

The 304 stainless steel showed pitting and crevice corrosion to the extent that the use of this material in direct contact with the hot geothermal fluid is not recommended. The flat AISI 316 stainless steel coupons were superior to the AISI 304 stainless steel coupons; however, the AISI 316 stainless steel tubes in the tube-to-tubesheet test showed definite pitting. AISI 316 stainless steel is not recommended until longer-term tests show this material to be stable in the hot geothermal fluid.

Both alloys $6 \mathrm{X}$ and 216 were significantly better than the AISI 304 stainless steel and somewhat superior to the AISI 316 stainless steel. Except for some minor pitting, the corrosion in these alloys appeared to be of the order of the surface roughness of the coupons. The use of Allegheny-Ludlum $6 X$ and 216 alloys is recommended where their mechanical properties can be used to advantage.

Ferritic Stainless Steels. Ferritic stainless steels are usually more difficult to fabricate and less corrosion-resistant than the austenitic materials. Two grades of ferritic stainless steel were tested: Allegheny-Ludlum alloys 29-4 and 29-4-2. These materials showed outstanding resistance to corrosion in the RRGE 1 geothermal fluid environment. These materials are recommended for use where their mechanical properties can be used to advantage. 
Nickel-Base Alloys. Hastelloy $G$ and Inconel 625 were the two nickel-base alloys tested in the RRGR 1 geothermal fluid. Hastelloy $G$ showed some minor pitting in both the flat coupon tests and in the tubeto-tubesheet test. This is a wear-resistant alloy and where this property is required, the use of Hastelloy $G$ is recommended.

Inconel 625 gave outstanding performance in all tests. The use of this material in contact with the geothermal fluid is recommended if its mechanical and physical properties are adequate.

Cobalt-Base Alloys. Haynes 6B, the only cobalt-base alloy used in the foregoing test, gave very good performance. This is wear-resistant material and its use in contact with the geothermal fluid is recommended where this property is required.

Ti.tanium. ASTM B 265, Grades 2 and 12, titanium were used in several tests. This material has given outstanding performance in all tests and its use is highly recommended. One precautionary note should be made. Crevice corrosion of the metal is possible in other metal-tometal joints or in contact with TFE at temperatures above about $149^{\circ} \mathrm{C}$ $\left(300^{\circ} \mathrm{F}\right)$. Since the Raft River geothermal fluids are tending toward this temperature in the hotter wells, care should be taken in selecting titanium without further testing. 


\section{REFERENCES}

1. A. A. Frost and R. G. Pearson, Kinetics and Mechanisms, New York: John Wiley and Sons, Inc., 1953, p 23.

2. G. Butler and H. C. K. Ison, Corrosion and Its Prevention in Waters, New York: Reinhold Publishing Corp., 1966.

3. H. R. Copson, "Effects of Velocity on Corrosion by Water", Ind. Eng. Chem, 44 (1952) p 1745.

4. A. H. Tuthill and C. M. Schillmoller, "Guidelines for Selection of Marine Materials", The Ocean Science and Ocean Engineering Conference, Marine Technology Society, Washington, D. C., June 14-17, 1965.

5. G. Butler and E. G. Stroud, "The Influence of Movement and Temperature on the Corrosion of Mild Steel. III. Chloride Solutions", British Corrosion Journal, I (1965) pp 110-119.

6. B. C. Syrett, "Erosion-Corrosion of Copper-Nickel Alloys in Sea Water and Other Aqueous Environments-A Literature Review", Corr., 32 (6) (June, 1976) pp 242-252.

7. K. D. Efird, "Effect of Fluid Dynamics on the Corrosion of Copper-Base Alloys in Sea Water", Corr., 33 (1) (January, 1977) pp 38.

8. J. Gilluly, A. C. Waters and A. 0. Woodford, Principles of Geology, 3rd Ed., San Francisco: W. H. Freeman and Co., 1968, p 24.

9. J. A. Whelan, Great Salt Lake, Utah: Chemical and Physical Variations of the Brine, 1966-1972, Utah Geological and Mineralogical Survey, Water-Resources Bulletin 17 (June, 1973). 
10. M. A. Cook, Prehistory and Earth Models, London: Max Parrish, 1966.

11. Handbook of Chemistry and Physics, 50th Ed., R. C. Weast, Editor, Cleveland, Ohio: The Chemical Rubber Co., 1969.

12. J. D. Hem, Study and Interpretation of Chemical Characteristics of Natural Water, 2nd Ed., U. S. Geological Survey, Water-Supply Paper 1473 (1970).

13. R. T. Foley, Complex Formation in Metal Dissolution and Metal Treatment, U. S. NTIS Report No. AD A037404, Washington, D.C.: The American University (March, 1977).

14. B. F. Brown, "Concept of the Occluded Corrosion Cel1", Corr., 26, (8) (1970) pp 249-250.

15. T. Suzuki, M. Yamabe, and Y. Kitamura, "Composition of Anolyte Within Pit Anode of Austenitic Stainless Steels in Chloride Solution", Corr., 29, (1) (1973) pp 18-22.

16. J. Mankowski and Z. Szklarska-Smialowska, "Studies on Accumulation of Chloride Ions in Pits Growing During Anodic Polarization", Corr. Sci., 15 (1975) pp 493-501.

17. H. H. Strehblow and M. B. Ives, "On the Electrochemical Conditions Within Small Pits", Corr. Sci., 16 (1976) pp 317-321.

18. R. M. Garrels and C. L. Christ, Solutions, Minerals and Equilibria, New York: Harper and Row, 1965.

19. The Corrosion Handbook, H. H. Uhlig, Editor, New York: John Wiley and Sons, 1948.

20. H. A. Todhunter, "Condenser Tubes in Sea Water Service", Power (March, 1967). 
21. J. F. Bates and J. M. Popplewel1, "Corrosion of Condenser Tube Alloys in Sulfide Contaminated Brine," Corr., 31 (8) (August, 1975) pp 269-275.

22. M. H. Froning, M. W. Shanley and E. D. Verink, Jr., "An Improved Method for Calculation of Potential-pH Diagrams of Metal-Ion-Water Systems by Computer", Corr. Sci., 16 (1976) pp 371-377.

23. J. C. Cowan and D. J. Weintritt, Water-Formed Scale Deposits, Houston, Texas: Gulf Publishing Co., 1976.

24. G. Butler and A. D. Mercer, "Effect of Glass Dissolution on Corrosion Measurements", Nature, 256 (5520) (August 28, 1975) pp 719-720.

25. A. Wachter and R. S. Treseder, "Corrosion Testing: Evaluation of Metals for Process Equipment", Chem. Eng. Prog., 43 (6) (1974) pp 315-326.

26. "Standard Recommended Practices for Conducting Plant Corrosion Tests, G 4-68", 1968 Annual Book of ASTM Standards, Philadelphia: American Society for Testing and Materials, 1968.

27. "Standard Methods of Test for Corrosivity of Water in the Absence of Heat Transfer, D 2688-70", 1970 Annual Book of ASTM Standards, Philadelphia: American Society for Testing and Materials, 1970.

28. "Laboratory Corrosion Testing of Metals for the Process Industries", NACE Standard TM-01-69, Houston: National Association of Corrosion Engineers, 1969. 
29. W. H. Ailor, Handbook on Corrosion Testing and Evaluation, New York: John Wiley and Sons, 1971.

30. E. D. Verink, Jr., "Aluminum Alloys for Saline Waters", Chem. Eng., 81 (Apri1 15, 1974) pp 104-110.

31. F. W. Fink and W. K. Boyd, The Corrosion of Metals in Marine Environments, DMIC Report 245, Columbus, Ohio: Battelle Memorial Institute, May 1970.

32. A. H. Tuthill and D. A. Sudrabin, "Why Copper-Nickel Alloys for Desal-ination", Metals Eng. Quart., (August, 1967).

33. S. Sato, "Corrosion and Its Prevention in Copper Alloy Condenser Tubes Under Modern Conditions", Rev. Coatings and Corr., I (2) (1973) pp 139-184.

34. J. Papamarcos, "Condenser Tube Design: Directions", Power Eng., (July, 1973) pp 24-31.

35. M. H. Peterson and T. J. Lennon, Jr., The Corrosion Behavior of Stainless Steels in Sea Water, Naval Research Laboratory, Memorandum Report 1795 (June, 1967).

36. C. A. Allen, Allied Chemical Co., private communication, (June 1, 1976).

37. Metals Handbook, T. Lyman, Ed., Cleveland, OH: The American Society for Meta 1s, 1948.

38. J. R. Maurer, "New Austenitic and Ferritic Stainless Steels", Proceedings of the Workshop on Materials Problems Associated with the Development of Energy Systems, Geothermal Resources Council, El Centro, Calif:, May 16-18, 1975. 
39. Resistance to Corrosion, Huntington Alloy Products Division, Publication S-37, 1970.

40. Titanium Tubes for Refinery Heat Exchangers, Titanium Metals Corporation of America, Bulletin RT-1, November, 1975.

41. Titanium for Industrial Brine and Sea Water Service, Titanium Metals Corporation of America, May 6, 1968.

42. L. C. Covington and H. R. Palmer, "A New Corrosion Resistant Titanium Alloy, TI-38A, for High Temperature Brine Service", Corrosion and Biomedical Applications for Titanium, AIME Symposium, 0ct. 21-24, 1974.

43. ARMCO 17-4 PH, Precipitation Hardening Stainless Steel Sheets and Strip, Baltimore: ARMCO Steel Corporation, Product Data Bulletin S-9b, 1972.

44. G. L. Mines and J. F. Whitbeck, "Heat Exchanger Fouling Tests at Raft River", Geothermal: State of the Art, Transactions of the Geothermal Resources Council, Annual Meeting, San Diego, Calif., May 9-11, 1977, pp 221-223. 
APPENDIX A

\section{COMPOSITION OF ALLOYS USED IN TESTS}

Since the composition of the various alloys adds relatively little to the immediate discussion of materials it was decided to collect the pertinent data on the materials in this appendix.

Table A-I summarizes the materials used in each test.

Table A-II gives the nominal composition of the aluminum alloys tested.

Table A-III gives the nominal composition of the copper-base alloys and Monel 400 used in these tests.

TabTe A-IV gives the nominal composition of the iron-base alloys used in the tests, including plain carbon and low alloy steels, gray cast iron and stainless steels.

Table A-V gives the nominal composition of the nickel-base alloys, except Monel 400, used in the tests.

Table A-VI gives the nominal composition of the titanium-base alloys and the only cobalt-base alloy, Haynes 6B, used in the tests. 
TABLE A-I

SUMMARY OF ALLOYS USED IN VARIOUS MATERIALS TESTS

\begin{tabular}{|c|c|c|c|c|}
\hline Alloy & Screening & $\begin{array}{c}\text { First } \\
\text { Short-Term }\end{array}$ & $\begin{array}{l}\text { Tube- to } \\
\text { Tubesheet }\end{array}$ & $\begin{array}{l}\text { Heat } \\
\text { Exchanger }\end{array}$ \\
\hline Steel Plate (AISI 1018) & $x$ & $x$ & & \\
\hline Steel Plate (ASTM A515) & $x$ & $x$ & & \\
\hline Steel Tubing (ASTM A179) & & & $x$ & $x$ \\
\hline Gray Cast Iron & $x$ & & & \\
\hline $9 \%$ Cr Steel (ASTM A182 Gr. F9) & $x$ & $x$ & & \\
\hline Cor-Ten & $x$ & $x$ & & \\
\hline AISI 4140 & $x$ & $x$ & & \\
\hline Haynes 6B & $x$ & $x$ & & \\
\hline Hastelloy G & $x$ & $x$ & $\mathrm{x}$ & \\
\hline Inconel 625 & $x$ & $x$ & & \\
\hline Mone1 400 & $x$ & & & \\
\hline $90 \mathrm{Cu} / 10 \mathrm{Ni}$ & $x$ & & & \\
\hline $70 \mathrm{Cu} / 30 \mathrm{Ni}$ & $x$ & & $x$ & \\
\hline AMPCO 8 & $x$ & $x$ & & \\
\hline AMPCO 12 & $x$ & $x$ & & \\
\hline AMPCO 483 & & $x$ & & \\
\hline CA 280 (Muntz Metal) & $x$ & & & \\
\hline CA 443 (Admiralty Brass) & & & $x$ & $x$ \\
\hline (Arsenic-stabilized) & & & & \\
\hline CA 464 (Naval Brass) & & & & $\mathrm{x}$ \\
\hline 1100 Aluminum & $x$ & & & \\
\hline 5052 Aluminum & $x$ & & & \\
\hline 6061 Aluminum & $x$ & & & \\
\hline Allegheny-Ludl um 29-4-2 & & $x$ & & \\
\hline Allegheny-Ludlum 29-4 & & $x$ & & \\
\hline Titanium & & $x$ & & \\
\hline Allegheny-Ludlum 216 & & $x$ & & \\
\hline Allegheny-Ludium $6 x$ & & $x$ & $x$ & \\
\hline AISI 304 SS & & $x$ & $x$ & $x$ \\
\hline AISI 316 & & $x$ & $x$ & $x$ \\
\hline AISI 410 & & $x$ & & \\
\hline AISI 440 & & $x$ & & \\
\hline
\end{tabular}




\section{TABLE A-II}

NOMINAL COMPOSITIONS OF ALUMINUM ALLOYS

\begin{tabular}{|c|c|c|c|c|c|c|}
\hline $\begin{array}{l}\text { Standards } \\
\text { Designation }\end{array}$ & $\begin{array}{l}\text { Common or } \\
\text { Commercial Name }\end{array}$ & A1 & $\begin{array}{l}\text { Nomina } 1 \\
\mathrm{Mg}\end{array}$ & $\begin{array}{c}\text { Composition } \\
\mathrm{Cr}\end{array}$ & $\mathrm{Cu}$ & Si \\
\hline $\begin{array}{l}\text { Aluminum alloy } 1100 \\
\text { Aluminum alloy } 5052 \\
\text { Aluminum alloy } 6061\end{array}$ & $\overline{---}$ & $\begin{array}{l}99.0 \text { min. } \\
\text { Bal } \\
\text { Bal }\end{array}$ & $\frac{-}{2.5}$ & $\begin{array}{l}- \\
0.25 \\
0.25\end{array}$ & $\begin{array}{l}- \\
\overline{0} .25\end{array}$ & $\begin{array}{l}\overline{-} \\
\overline{0} .6\end{array}$ \\
\hline
\end{tabular}


TABLE A-III

COPPER ALLOYS EVALUATED FOR GEOTHERMAL SERVICE

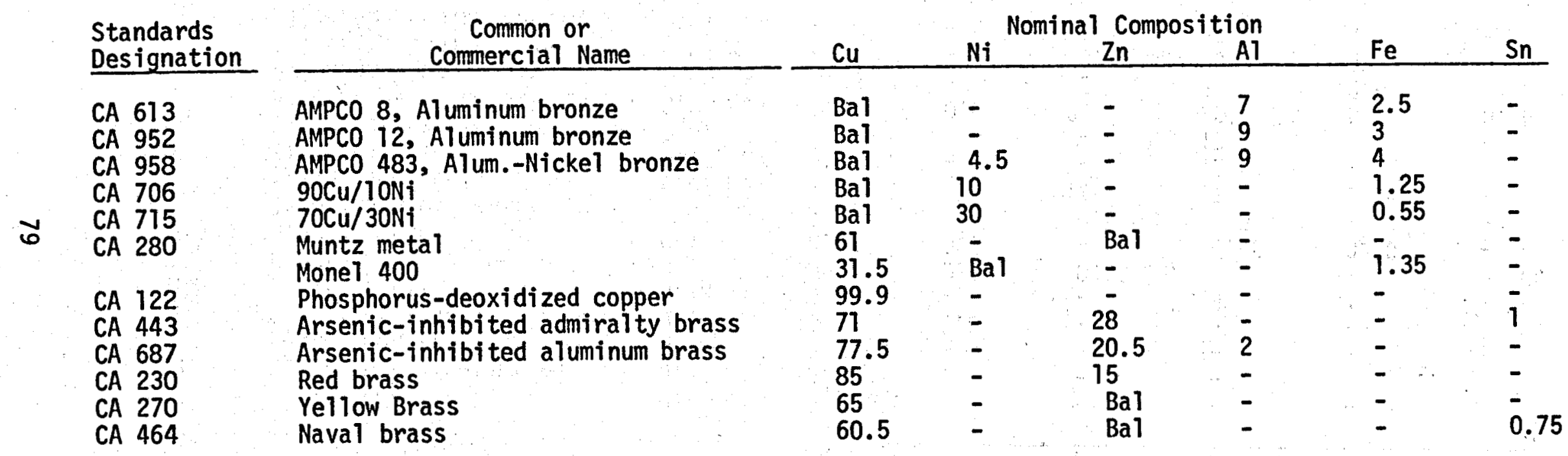


TABLE A-IV

IRON-BASE ALLOYS EVALUATED FOR GEOTHERMAL SERVICE

\begin{tabular}{|c|c|c|c|c|c|c|c|c|}
\hline $\begin{array}{l}\text { Standards } \\
\text { Designation }\end{array}$ & $\begin{array}{c}\text { Common or } \\
\text { Commercial Name }\end{array}$ & C & $\mathrm{Mn}$ & Si & $\begin{array}{l}1 \text { Composit } \\
\mathrm{Ni}\end{array}$ & $\begin{array}{r}\text { tion } \\
\mathrm{Cr}\end{array}$ & Mo & Other \\
\hline $\begin{array}{ll}\text { AISI } & 1018 \\
\text { ASTM A } & 515 \\
\text { ASTM A } & 179 \\
\text { ASTM A } & 48 \\
\text { ASTM A } 182 \\
\text { ASTM A } 242 \\
\text { AISI } 4140 \\
\text { AISI } 304 \\
\text { AISI } 316 \\
\text { AISI } 410 \\
\text { AISI } 440 A\end{array}$ & $\begin{array}{l}\text { Low-carbon steel } \\
\text { Low-carbon steel plate } \\
\text { Low-carbon steel tubing } \\
\text { Gray cast iron } \\
9 \% \text { Cr steel } \\
\text { Cor-ten } \\
\text { AISI } 4140 \\
18 / 8 \text { Stainless steel } \\
\text { Stainless steel } \\
\text { Stainless steë1 } \\
\text { Stainless steel } \\
\text { Allegheny-Ludlum } 6 x \\
\text { Allegheny-Ludlum } 216 \\
\text { Allegheny-Ludlum } 29-4 \\
\text { Allegheny-Ludfum } 29-4-2\end{array}$ & $\begin{array}{l}0.20 \max \\
0.24 \max \\
0.72 \\
3.4 \\
0.12 \\
0.12 \\
0.4 \\
0.08 \max \\
0.08 \max \\
0.15 \max \\
0.67 \\
0.03 \max \\
0.08 \max \\
0.01 \max \\
0.01 \max \end{array}$ & $\begin{array}{l}0.9 \max \\
0.75 \\
0.45 \\
0.8 \\
0.6 \\
0.4 \\
0.87 \\
- \\
- \\
- \\
- \\
1.5 \\
8.25 \\
- \\
-\end{array}$ & $\begin{array}{l}- \\
- \\
\overline{1} .8 \\
- \\
0.5 \\
0.3 \\
- \\
- \\
- \\
- \\
0.5 \\
- \\
-\end{array}$ & $\begin{array}{l}- \\
- \\
- \\
- \\
- \\
0.65 \mathrm{max} \\
\overline{9} \\
9.5 \\
12 \\
- \\
\overline{24} \\
6 \\
0.15 \max \\
2\end{array}$ & $\begin{array}{l}- \\
- \\
- \\
\overline{9} \\
\overline{0} \\
0.95 \\
18.5 \\
17 \\
12 \\
17 \\
20 \\
20 \\
29 \\
29\end{array}$ & $\begin{array}{l}- \\
- \\
- \\
\overline{1} \\
\overline{1} \\
\overline{0} .20 \\
\overline{2} .25 \\
\overline{-} \\
\overline{6} .0 \\
2.5 \\
4 \\
4\end{array}$ & $\begin{array}{l}- \\
- \\
- \\
- \\
- \\
0.4 \mathrm{CU} \\
- \\
- \\
- \\
- \\
- \\
0.3 \mathrm{~N} \\
- \\
- \\
-\end{array}$ \\
\hline
\end{tabular}


TABLE A-V

NICKEL-BASE ALLOYS EVALUATED FOR GEOTHERMAL SERVICE

\begin{tabular}{|c|c|c|c|c|c|c|c|c|c|}
\hline $\begin{array}{l}\text { Standards } \\
\text { Designation }\end{array}$ & $\begin{array}{c}\text { Common or } \\
\text { Commercial Name }\end{array}$ & $\mathrm{Co}$ & $\mathrm{Cr}$ & Mo & $\begin{array}{c}\text { Nominal } \\
\mathrm{W}\end{array}$ & $\begin{array}{c}\text { Composition } \\
\mathrm{Fe} \\
\end{array}$ & $\mathrm{Cu}$ & $\mathrm{Cb}+\mathrm{Ta}$ & Other \\
\hline & $\begin{array}{l}\text { Hastelloy G } \\
\text { Inconel } 625\end{array}$ & $\begin{array}{l}2.5 \\
-\end{array}$ & $\begin{array}{l}22.5 \\
21.5\end{array}$ & $\begin{array}{l}6.5 \\
9\end{array}$ & $\begin{array}{l}1 \\
-\end{array}$ & $\begin{array}{r}19.5 \\
2.5\end{array}$ & $\begin{array}{l}2 \\
-\end{array}$ & $\begin{array}{l}2 \\
3.65\end{array}$ & $\begin{array}{l}- \\
0.2 A T \\
0.2 T i\end{array}$ \\
\hline
\end{tabular}

$\stackrel{\infty}{0}$ 


\section{TABLE A-VI}

NOMINAL COMPOSITIONS OF TITANIUM

AND COBALT ALLOYS TESTED

\begin{tabular}{|c|c|c|c|c|c|c|c|c|}
\hline $\begin{array}{l}\text { Standards } \\
\text { Designation }\end{array}$ & $\begin{array}{c}\text { Common or } \\
\text { Commercial Name }\end{array}$ & Ti & Mo & $\begin{array}{l}\text { Nominal } \\
\text { Co }\end{array}$ & $\begin{array}{c}\text { Compositions } \\
\mathrm{Ni}\end{array}$ & $\mathrm{Cr}$ & $W$ & C \\
\hline $\begin{array}{l}\text { ASTM B 265 } \\
\text { (Grade 2) }\end{array}$ & $\begin{array}{l}\text { Commercially pure } \\
\text { titanium }\end{array}$ & $\mathrm{Bal}$ & - & - & - & - & - & - \\
\hline \multirow{2}{*}{$\begin{array}{l}\text { ASTM B 265 } \\
\text { (Grade 12) }\end{array}$} & TIMET TiCode-12 & $\mathrm{Bal}$ & 0.3 & - & 0.8 & - & - & - \\
\hline & Haynes $A 110 y 6 B$ & - & - & $\mathrm{Bal}$ & 3 & 30 & 4.5 & 1.15 \\
\hline
\end{tabular}




\section{DISTRIBUTION RECORD FOR TREE-1176}

\section{Internal Distribution}

1 - Chicago Patent Group - DOE 9800 South Cass Avenue Argonne, Illinois 60439

1 - C. A. Benson Idaho Operations office-DOE Idaho Falls, ID 83401

1 - H. P. Pearson, Supervisor Technical Information

10 - INEL Technical Library

20 - Authors

25 - Special Internal

External Distribution

185 - Special External

531 - UC-66d - GE-Exploration Technology, TID-4500-R66

Total Copies Printed - 774 